\title{
Effect of Temperature on the Tensile Properties of a Commercial and a High-Purity 70-Percent-Nickel-30-Percent-Copper Alloy
}

\author{
William D. Jenkins, Thomas G. Digges, and Carl R. Johnson
}

\begin{abstract}
Short-time tensile tests were made at temperatures ranging from $75^{\circ}$ to $1,700^{\circ} \mathrm{F}$ on two 70-percent-nickel-30-percent-copper alloys. The experimental evidence showed that discontinuous flow occurred in specimens of both alloys fractured in tension at temperatures ranging from $300^{\circ}$ to $1700 \mathrm{~F}$. This phenomenon was attributed to strain-aging at the lower temperatures and to recrystallization accompanied by grain growth at the higher temperatures. Variations in chemical composition of the two alloys also affected the degree of strain-aging, strength and ductility properties, and fracture characteristics.
\end{abstract}

\section{Introduction}

Tensile tests were made at temperatures ranging from $75^{\circ}$ to $1,700^{\circ} \mathrm{F}$ on two lots of 70 -percentnickel-30-percent-copper alloys of the same initial grain size and structure but differing in purity. One alloy was of relatively high purity, whereas the other was a commercial grade that contained appreciable amounts of manganese, iron, and cobalt. The tensile properties of the high-purity alloy as evaluated at a lower range of temperatures $\left(-320^{\circ}\right.$ to $\left.212^{\circ} \mathrm{F}\right)$ have been investigated [1], ${ }^{1}$ and a study of its creep behavior is now in progress.

\section{Previous Investigations}

The influence of temperature on the mechanical properties of commercial grades of 70-percent-nickel30-percent-copper alloys (Monel) has been discussed in several publications $[2,3]$, but little information is available on the effect of impurities on these properties. An inspection of the results given in the tables [2] shows that the tensile strength of hot-rolled Monel increased as the test temperature was raised from $500^{\circ}$ to $600^{\circ} \mathrm{F}$ without a corresponding decrease in elongation. However, in the range of $1,000^{\circ}$ to $1,300^{\circ} \mathrm{F}$ there is a definite increase in brittleness, accompanied by a loss of strength. McVetty and Mochel [4] reported a precipitous drop in values for tensile strength and ductility of hot-rolled Monel as the test temperature was increased from $750^{\circ}$ to $930^{\circ} \mathrm{F}$.

Some creep properties of Monel have been reported by Bennett and McAdam [5], McAdam, Geil, and Woodard [6], Grant and Bucklin [7], Shahinian and Lane [8], and Betty, Eiselstein, and Huston [9]. Indications of the onset of intercrystalline fracture, aging, and discontinuity in temperature-ductility relations are evident in some of the results presented.

1 Figures in brackets indicate the literature references at the end of this paper.

\section{Alloys and Testing Procedures}

The chemical composition of the alloys investigated is given in table 1 .

The charges were melted in an induction furnace, and each alloy was cast into a 14 - by 14 - by 60 -in. ingot. The ingots were milled, then forged to 8by 8 -in. blooms, hot-rolled to $2 \frac{1}{2}$-in. square billets, and then hot-rolled to $7 / 8$-in. rounds. The round bars were annealed at $1,100^{\circ} \mathrm{F}$. for $16 \mathrm{hr}$, then at $1,000^{\circ} \mathrm{F}$ for $8 \mathrm{hr}$. The alloys, as supplied by the manufacturer in the above condition, had an average grain diameter of $0.025 \mathrm{~mm}$. The structures of these alloys are shown in figure $19, \mathrm{~A}$ and $\mathrm{B}$.

Tensile specimens, 0.505 -in. diameter and with 2.0 -in. reduced sections, were machined from one bar of each alloy. Each specimen was heated in air in an automatically controlled electric furnace and held at the desired temperature for approximately $1 \mathrm{hr}$ before testing in tension; the specimen was maintained within $\pm 3 \mathrm{deg} F$ of the desired temperature. The specimens were tested in a hydraulic-type machine, with the specimen and

TABLE 1. Chemical composition (percentage by weight) of the alloys used

\begin{tabular}{|c|c|c|c|c|c|c|}
\hline \multirow{2}{*}{ Designation } & \multicolumn{6}{|c|}{ Chemical composition } \\
\hline & $\mathrm{Ni}$ & $\mathrm{Cu}$ & Mn & $\mathrm{Fe}$ & $\mathrm{Si}$ & $\mathrm{C}$ \\
\hline \multirow{3}{*}{$\begin{array}{l}\text { High-purity } \\
\text { Commercial }\end{array}$} & 70.08 & 29. 71 & 0.01 & 0.01 & 0.12 & 0.017 \\
\hline & 66.97 & 29. 79 & .89 & 1. 56 & .17 & .15 \\
\hline & $\mathrm{S}$ & $\mathrm{Ca}$ & $\mathrm{Co}_{0}$ & $\mathrm{O}_{2}$ & $\mathrm{~N}_{2}$ & $\mathrm{H}_{2}$ \\
\hline High-purity & 0.002 & (1) & $(2)$ & 0.001 & 0.0015 & 0.0003 \\
\hline Commercial & .006 & 0.017 & 0.38 & .0001 & None & .0001 \\
\hline
\end{tabular}

1 Faint trace.

2 Not detected. 
adapter occupying about $3 \mathrm{ft}$ between two selfalining holders. The movement of the head during the test was recorded by means of a stress-strain recorder of the Templin type. Except for some specimens tested at $600^{\circ} \mathrm{F}$, as noted in tables 2 and 3 , the movement of the head of the machine was con- trolled to produce a rate of strain of about 1 percent a minute.

Hardness tests and metallographic examinations were carried out at room temperature on the fractured specimens in accordance with previously described procedures [10].

TABLE 2. Results of tensile tests on high-purity 70-percent-nickel-30-percent-copper alloy

Usual rate of strain, 1 percent a minute. Specimens at $600^{\circ} \mathrm{F}$ were tested (A) at usual speed, (B) to complete fracture in 21 min (speed test), (C) to complete fracture in $4 \mathrm{~min}$ (superspeed test).

\begin{tabular}{|c|c|c|c|c|c|c|c|c|c|c|c|c|c|}
\hline \multirow{3}{*}{$\begin{array}{l}\text { Temper- } \\
\text { ature }\end{array}$} & \multirow{3}{*}{$\begin{array}{c}\text { Yield } \\
\text { strength } \\
(0.2 \% \\
\text { offset })\end{array}$} & \multicolumn{3}{|c|}{ Drop of beam } & \multicolumn{5}{|c|}{ Maximum load } & \multirow{3}{*}{$\begin{array}{l}\text { Fracture } \\
\text { strength }\end{array}$} & \multirow{3}{*}{$\begin{array}{l}\text { Elonga- } \\
\text { tion in } \\
2 \text { in. }\end{array}$} & \multirow{3}{*}{$\begin{array}{l}\text { Reduc- } \\
\text { tion of } \\
\text { area }\end{array}$} & \multirow{3}{*}{$\begin{array}{c}\text { True } \\
\text { strain at } \\
\text { complete } \\
\text { fracture a }\end{array}$} \\
\hline & & \multirow{2}{*}{$\begin{array}{l}\text { Stress at } \\
\text { first drop } \\
\text { of beam }\end{array}$} & \multicolumn{2}{|c|}{ Maximum drop } & \multirow{2}{*}{$\begin{array}{l}\text { Tensile } \\
\text { strength }\end{array}$} & \multirow{2}{*}{$\begin{array}{l}\text { True } \\
\text { stress }\end{array}$} & \multirow{2}{*}{ Strain } & \multirow{2}{*}{$\begin{array}{l}\text { Reduc- } \\
\text { tion in } \\
\text { area }\end{array}$} & \multirow{2}{*}{$\begin{array}{l}\text { True } \\
\text { strain }\end{array}$} & & & & \\
\hline & & & $\begin{array}{c}\text { Stress at } \\
\text { occurrence } \\
\text { of }\end{array}$ & $\underset{\text { drop }}{\text { Amount of }}$ & & & & & & & & & \\
\hline $\begin{array}{l}\circ F \\
75 \\
212 \\
300 \\
500\end{array}$ & $\begin{array}{l}l b / i n .^{2} \\
26,500 \\
25,250 \\
24,050 \\
23,600\end{array}$ & $\begin{array}{c}l b / i n .^{2} \\
\text { None } \\
\text { None } \\
25,700 \\
25,350\end{array}$ & $\begin{array}{l}\text { lb/in. } .^{2} \\
\text { None } \\
\text { None } \\
25,700 \\
60,800\end{array}$ & $\begin{array}{r}\text { lb/in. } .^{2} \\
\text { None } \\
\text { None } \\
130 \\
1,370\end{array}$ & $\begin{array}{l}l b / \text { in }^{2} \\
67,350 \\
63,050 \\
61,850 \\
60,800\end{array}$ & $\begin{array}{c}l b / \text { in }^{2} \\
94,550 \\
85,200 \\
85,300 \\
83,500\end{array}$ & $\begin{array}{c}\% \\
40.4 \\
35.1 \\
37.9 \\
37.3\end{array}$ & $\begin{array}{l}\% \\
28.8 \\
26 \\
27.5 \\
27.2\end{array}$ & $\begin{array}{r}0.339 \\
.301 \\
.321 \\
.317\end{array}$ & $\begin{array}{c}\text { Zb/in.2 } \\
304,900 \\
321,500 \\
277,900 \\
247,400\end{array}$ & $\begin{array}{l}\% \\
59.1 \\
51 \\
52 \\
48.3\end{array}$ & $\begin{array}{l}\% \\
88.4 \\
89.3 \\
88 \\
85.5\end{array}$ & $\begin{array}{l}2.150 \\
2.235 \\
2.113 \\
1.929\end{array}$ \\
\hline $\begin{array}{l}600(\mathrm{~A}) \\
600(\mathrm{~B}) \\
600(\mathrm{C}) \\
700\end{array}$ & $\begin{array}{l}21,600 \\
22,500 \\
22,050 \\
23,400\end{array}$ & $\begin{array}{l}22,500 \\
22,700 \\
22,000 \\
23,400\end{array}$ & $\begin{array}{c}60,450 \\
50,000 \\
\text { (b) } \\
24,400\end{array}$ & $\begin{array}{c}1,575 \\
1,625 \\
(\mathrm{~b}) \\
875\end{array}$ & $\begin{array}{l}61,850 \\
60,400 \\
58,900 \\
59,950\end{array}$ & $\begin{array}{l}84,300 \\
83,100 \\
81,700 \\
81,250\end{array}$ & $\begin{array}{l}36.3 \\
37.5 \\
38.7 \\
35.5\end{array}$ & $\begin{array}{l}26.6 \\
27.3 \\
27.9 \\
26.2\end{array}$ & $\begin{array}{l}.309 \\
.318 \\
.327 \\
.304\end{array}$ & $\begin{array}{l}221,500 \\
216,300 \\
263,700 \\
227,800\end{array}$ & $\begin{array}{l}51 \\
49 \\
50 \\
49.2\end{array}$ & $\begin{array}{l}85 \\
86 \\
85.7 \\
84.1\end{array}$ & $\begin{array}{l}1.894 \\
1.964 \\
1.948 \\
1.840\end{array}$ \\
\hline $\begin{array}{r}800 \\
900 \\
1,000 \\
1,100\end{array}$ & $\begin{array}{l}22,150 \\
19,950 \\
17,500 \\
16,700\end{array}$ & $\begin{array}{r}22,500 \\
33,000 \\
\text { None } \\
\text { None }\end{array}$ & $\begin{array}{c}54,500 \\
33,000 \\
\text { None } \\
\text { None }\end{array}$ & $\begin{array}{r}1,500 \\
500 \\
\text { None } \\
\text { None }\end{array}$ & $\begin{array}{l}55,300 \\
50,050 \\
42,050 \\
31,400\end{array}$ & $\begin{array}{l}73,650 \\
65,800 \\
53,400 \\
38,450\end{array}$ & $\begin{array}{l}33.1 \\
31.4 \\
27 \\
22.5\end{array}$ & $\begin{array}{l}24.9 \\
23.9 \\
21.3 \\
17.9\end{array}$ & $\begin{array}{l}.286 \\
.273 \\
.239 \\
.203\end{array}$ & $\begin{array}{r}190,300 \\
153,500 \\
98,300 \\
53,100\end{array}$ & $\begin{array}{l}45.2 \\
46.8 \\
47 \\
42\end{array}$ & $\begin{array}{l}81.7 \\
78.7 \\
71.6 \\
66.5\end{array}$ & $\begin{array}{l}\text { 1. } 698 \\
\text { 1. } 546 \\
\text { 1. } 257 \\
1.098\end{array}$ \\
\hline $\begin{array}{l}1,200 \\
1,350 \\
1,500 \\
1,700\end{array}$ & $\begin{array}{r}13,500 \\
9,700 \\
5,750 \\
4,500\end{array}$ & $\begin{array}{r}\text { None } \\
15,700 \\
10,250 \\
1,625\end{array}$ & $\begin{array}{r}\text { None } \\
15,700 \\
10,250 \\
5,650\end{array}$ & $\begin{array}{r}\text { None } \\
25 \\
50 \\
125\end{array}$ & $\begin{array}{r}24,300 \\
15,800 \\
10,300 \\
5,850\end{array}$ & $\begin{array}{r}27,550 \\
17,700 \\
11,250 \\
6,600\end{array}$ & $\begin{array}{r}13.3 \\
12.1 \\
9.2 \\
13.4\end{array}$ & $\begin{array}{r}11.7 \\
10.8 \\
8.4 \\
11.8\end{array}$ & $\begin{array}{l}.125 \\
.114 \\
.087 \\
.127\end{array}$ & $\begin{array}{r}26,800 \\
19,200 \\
9,800 \\
6,400\end{array}$ & $\begin{array}{l}37.5 \\
35 \\
47 \\
47.5\end{array}$ & $\begin{array}{l}58.1 \\
49.4 \\
49 \\
45\end{array}$ & $\begin{array}{r}0.869 \\
.681 \\
.671 \\
.598\end{array}$ \\
\hline
\end{tabular}

a The true strain at complete fracture was based on the minimum cross-sectional area of the fractured specimen at room temperature.

b Not determined.

TABLE 3. Results of tensile tests on commercial \%O-percent-nickel-30-percent-copper alloy

Usual rate of strain, 1 percent a minute. Specimens at $600^{\circ} \mathrm{F}$ were tested (A) at usual speed, (B) to complete fracture in 24.8 min (speed test).

\begin{tabular}{|c|c|c|c|c|c|c|c|c|c|c|c|c|c|}
\hline \multirow{3}{*}{$\begin{array}{l}\text { Temper- } \\
\text { ature }\end{array}$} & \multirow{3}{*}{$\begin{array}{c}\text { Yield } \\
\text { strength } \\
(0.2 \% \\
\text { offset })\end{array}$} & \multicolumn{3}{|c|}{ Drop of beam } & \multicolumn{5}{|c|}{ Maximum load } & \multirow{3}{*}{$\begin{array}{l}\text { Fracture } \\
\text { strength }\end{array}$} & \multirow{3}{*}{$\begin{array}{l}\text { Elonga- } \\
\text { tion in } \\
2 \text { in. }\end{array}$} & \multirow{3}{*}{$\begin{array}{l}\text { Reduc- } \\
\text { tion of } \\
\text { area }\end{array}$} & \multirow{3}{*}{$\begin{array}{c}\text { 'Irue } \\
\text { strain at } \\
\text { complete } \\
\text { fracture }\end{array}$} \\
\hline & & \multirow{2}{*}{$\begin{array}{l}\text { Stress at } \\
\text { first drop } \\
\text { of beam }\end{array}$} & \multicolumn{2}{|c|}{ Maximum drop } & \multirow[b]{2}{*}{$\begin{array}{l}\text { Tensile } \\
\text { strength }\end{array}$} & \multirow[b]{2}{*}{$\begin{array}{l}\text { True } \\
\text { stress }\end{array}$} & \multirow[b]{2}{*}{ Strain } & \multirow{2}{*}{$\begin{array}{l}\text { Reduc- } \\
\text { tion in } \\
\text { area }\end{array}$} & \multirow[b]{2}{*}{$\begin{array}{l}\text { True } \\
\text { strain }\end{array}$} & & & & \\
\hline & & & $\begin{array}{c}\text { Stress at } \\
\text { occurrence } \\
\text { of }\end{array}$ & $\begin{array}{l}\text { Amount of } \\
\text { drop }\end{array}$ & & & & & & & & & \\
\hline $\begin{array}{l}\circ F \\
75 \\
212 \\
300 \\
500\end{array}$ & $\begin{array}{l}l b / \text { in }^{2} \\
42,000 \\
38,650 \\
36,700 \\
35,500\end{array}$ & $\begin{array}{c}l b / \text { in } .^{2} \\
\text { None } \\
\text { None } \\
\text { None } \\
35,600\end{array}$ & $\begin{array}{c}\text { lb/in. }{ }^{2} \\
\text { None } \\
\text { None } \\
\text { None } \\
81,250\end{array}$ & $\begin{array}{l}l b / i n .^{2} \\
\text { None } \\
\text { None } \\
\text { None } \\
350\end{array}$ & $\begin{array}{l}l b / \text { in }^{2} \\
88,250 \\
83,600 \\
82,400 \\
87,200\end{array}$ & $\begin{array}{c}l b / \text { in }^{2} \\
121,500 \\
110,100 \\
111,800 \\
120,400\end{array}$ & $\begin{array}{c}\% \\
37.7 \\
31.7 \\
35.7 \\
38.1\end{array}$ & $\begin{array}{c}\% \\
27.4 \\
24.1 \\
26.3 \\
27.6\end{array}$ & $\begin{array}{r}0.319 \\
.275 \\
.305 \\
.325\end{array}$ & $\begin{array}{c}\text { Tb/in. } \\
194.200 \\
188,600 \\
208,400 \\
210,000\end{array}$ & $\begin{array}{l}\% \\
51.8 \\
49 \\
48 \\
47.3\end{array}$ & $\begin{array}{c}\% \\
71.1 \\
68.3 \\
71.2 \\
67.6\end{array}$ & $\begin{array}{l}1.241 \\
1.148 \\
1.247 \\
1.127\end{array}$ \\
\hline $\begin{array}{l}600(\mathrm{~A}) \\
600(\mathrm{~B}) \\
700 \\
800\end{array}$ & $\begin{array}{l}34,600 \\
34,850 \\
33,800 \\
31,950\end{array}$ & $\begin{array}{r}38,000 \\
36,500 \\
37,250 \\
\text { None }\end{array}$ & $\begin{array}{r}44,750 \\
80,500 \\
37,250 \\
\text { None }\end{array}$ & $\begin{array}{r}2,000 \\
375 \\
50 \\
\text { None }\end{array}$ & $\begin{array}{l}82,750 \\
83,600 \\
75,800 \\
66,650\end{array}$ & $\begin{array}{r}113,500 \\
113,900 \\
102,900 \\
86,300\end{array}$ & $\begin{array}{l}37.2 \\
36.3 \\
35.7 \\
29.4\end{array}$ & $\begin{array}{l}27.1 \\
26.6 \\
26.3 \\
22.7\end{array}$ & $\begin{array}{l}.316 \\
.309 \\
.305 \\
.258\end{array}$ & $\begin{array}{l}162,500 \\
183,600 \\
179,200 \\
112,600\end{array}$ & $\begin{array}{l}48.6 \\
48 \\
45.5 \\
34.8\end{array}$ & $\begin{array}{l}63.8 \\
64.2 \\
67.7 \\
43.2\end{array}$ & $\begin{array}{l}1.016 \\
1.027 \\
1.131 \\
0.657\end{array}$ \\
\hline $\begin{array}{r}900 \\
1,000 \\
1,200 \\
1,350\end{array}$ & $\begin{array}{l}28,550 \\
24,950 \\
17,650 \\
11,900\end{array}$ & $\begin{array}{l}\text { None } \\
\text { None } \\
25,500 \\
15,650\end{array}$ & $\begin{array}{l}\text { None } \\
\text { None } \\
25,500 \\
15,650\end{array}$ & $\begin{array}{r}\text { None } \\
\text { None } \\
25 \\
50\end{array}$ & $\begin{array}{l}54,150 \\
41,950 \\
25,400 \\
15,950\end{array}$ & $\begin{array}{l}64,600 \\
51,750 \\
28,950 \\
16,750\end{array}$ & $\begin{array}{c}19.3 \\
23.3 \\
14 \\
5.1\end{array}$ & $\begin{array}{r}16.2 \\
18.9 \\
12.3 \\
4.9\end{array}$ & $\begin{array}{l}.175 \\
.209 \\
.131 \\
.051\end{array}$ & $\begin{array}{l}80,500 \\
63,900 \\
31,600 \\
16,500\end{array}$ & $\begin{array}{l}27.3 \\
27.3 \\
33.5 \\
28\end{array}$ & $\begin{array}{l}34.3 \\
36.4 \\
55.2 \\
40.1\end{array}$ & $\begin{array}{l}.420 \\
.452 \\
.803 \\
.512\end{array}$ \\
\hline $\begin{array}{l}1,500 \\
1,700\end{array}$ & $\begin{array}{l}6,760 \\
3,750\end{array}$ & $\begin{array}{l}9,350 \\
2,800\end{array}$ & $\begin{array}{l}9,350 \\
5,300\end{array}$ & $\begin{array}{l}100 \\
175\end{array}$ & $\begin{array}{l}9,600 \\
5,300\end{array}$ & $\begin{array}{l}9,750 \\
5,400\end{array}$ & $\begin{array}{l}1.8 \\
1.6\end{array}$ & $\begin{array}{l}1.8 \\
1.6\end{array}$ & $\begin{array}{l}.018 \\
.016\end{array}$ & $\begin{array}{l}6,700 \\
5,000\end{array}$ & $\begin{array}{l}24 \\
22\end{array}$ & $\begin{array}{l}26.2 \\
18.3\end{array}$ & $\begin{array}{l}.304 \\
.201\end{array}$ \\
\hline
\end{tabular}

a The true strain at complete fracture was based on the minimum cross-sectional area of the fractured specimen at room temperature. 


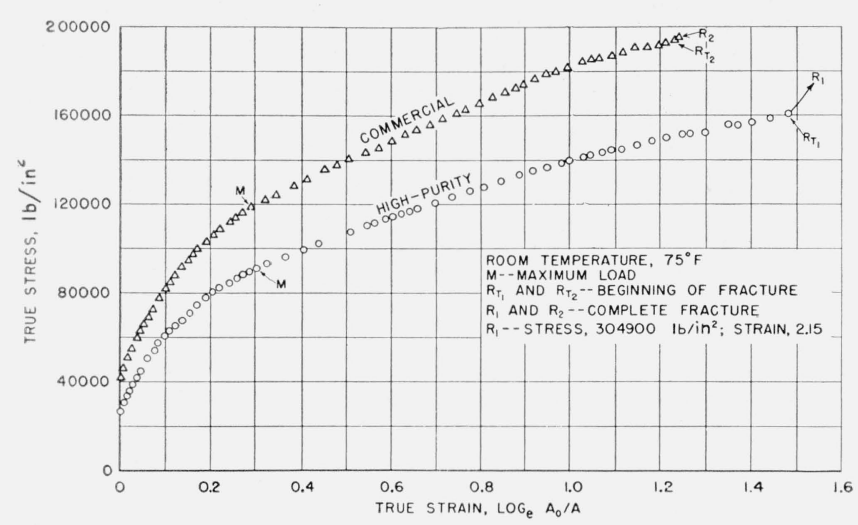

Figure 1. Relation of true stress to true strain for the alloys tested in tension at room temperature.

\section{Results and Discussion}

\subsection{Mechanical Properties}

The experimental results are summarized in tables 2 and 3 and in figures 1 to 22 . A comparison of the flow characteristics in tension of the alloys at room temperature is obtained by observing the relative positions of the true-stress-true-strain ${ }^{2}$ graphs in figure 1. The flow stresses at equal strains, stresses at maximum load $(M)$ and at beginning of fracture $\left(R_{T}\right)$, and rates of work-hardening were greater for the commercial than for the high-purity alloy. However, the true strains at maximum load and at the beginning of fracture and fracture strength ${ }^{3}$ were correspondingly greater for the high-purity alloy.

Photographs of many of the autographic stressstrain records obtained on specimens of the alloys tested at different temperatures are reproduced in figures 2, 3, and 4 . The rate of work-hardening varied with the amount of strain, the test temperature, and composition of the alloys. At the lower test temperatures, the slopes of the curves were relatively steep from the onset of plastic deformation to the maximum load. Precipitous drops in the curves in the region of maximum load to fracture are associated with necking of the specimens, whereas the flatness of some of the curves in this region is an indication of uniformity in deformation. At equal temperatures and strains, the rate of work hardening of the commercial alloy was usually somewhat higher than that of the high-purity alloy. Discontinuous flow occurred in many of the specimens as is indicated by the serrations in these curves. These serrations were often obtained both before and after the attainment of the maximum load on specimens of each alloy. Although the trend was for the serra-

\footnotetext{
2 The true stress was determined by dividing the current load by the current
minimum cross-sectional area of the specimen. The true strain was determined minimum cross-sectional area of the specimen. The true strain was determined as the natural logarithm of the ratio of the original cross-section
men $\left(A_{0}\right)$ to the current minimum cross-sectional area $(A)$.

men $\left(A_{0}\right)$ to the current minimum cross-sectional area $(A)$.
3 Fracture strength was determined by dividing the final load by the minimum cross-sectional area of the fractured specimen at room temperature.
}

tions to attain a maximum in the specimens tested at $600^{\circ} \mathrm{F}$, they were also observed in specimens tested at temperatures ranging from $300^{\circ}$ to $900^{\circ}$ $\mathrm{F}$, and were considerably more noticeable in the stress-strain curves obtained on specimens of the high-purity alloy (fig. 2) than in the curves for the commercial alloy (fig. 3). Furthermore, increasing the speed of testing (table 2) by a factor of about 15 did not materially decrease the magnitude of serrations in the curves for the specimens of the highpurity alloy tested at $600^{\circ} \mathrm{F}$ (compare curves $\mathrm{A}$ and C, fig. 2). The serrations are believed to be associated with strain-aging and other atomic rearrangements.

Discontinuous flow was obtained in specimens of both alloys tested at the higher temperatures, as is illustrated in figure 4 . The breaks in the stressstrain curves in the region of strains corresponding approximately from the drop of beam to nearly complete fracture are interpreted as being associated with recrystallization ${ }^{4}$ and grain growth (fig. 20, E and F; fig. 21, C and D; fig. 22, E and F).

The effect of temperature on the yield strengths of the two alloys is shown in figures 5,6 , and 7 . For the specimens tested at the usual rate, there appeared to be a continuous decrease in yield strength with increase in test temperature, with the exception of the specimens of high-purity alloy tested within the range of about $600^{\circ}$ to $700^{\circ} \mathrm{F}$ (fig. 5). The slopes of these curves were continuously changing, however, and the magnitude of the change was affected significantly by the composition of the materials; yield strengths of each alloy at $1,500^{\circ}$ or $1,700^{\circ} \mathrm{F}$ were approximately equal. Increasing the speed of application of load (points designated B) at $600^{\circ} \mathrm{F}$ raised the yield strengths slightly.

Certain investigators have indicated that a linear relationship exists between the yield strength and the reciprocal of the absolute (Kelvin) temperature when the experimental results are plotted on a linear or semilog (log of temperature) basis. The results obtained in the present investigation are plotted in these manners in figures 6 and 7 , respectively. These assumptions were found to be approximately valid for limited ranges of temperature, but for each alloy there is a considerable difference between the slopes of the curves at high and at low temperatures. Moreover, at equal temperatures, there is also a difference in the slopes of the curves in each of the diagrams for the two alloys. This suggests that the activation energy for flow is not a simple function of the applied stress, but rather a complex function involving stress, temperature, and the size of the flow units activated by temperature.

The tensile strength of each alloy decreased with an increase in test temperature from $75^{\circ}$ to $300^{\circ} \mathrm{F}$ (fig. 8). However, reversals were obtained in the

4 According to Patton (Metals Handbook, 1948, p. 1049), the commercial alloy recrystallizes at $1,220^{\circ}$ and $1,110^{\circ} \mathrm{F}$ for 10 - and 50 -percent reduction of area, respectively. 
tensile strength-temperature curves between $300^{\circ}$ and $500^{\circ} \mathrm{F}$ for the commercial alloy, and between $500^{\circ}$ and $600^{\circ} \mathrm{F}$ for the high-purity alloy. The tensile strength of each alloy decreased with a further increase in test temperature. Between $1,000^{\circ}$ to $1,700^{\circ} \mathrm{F}$, the tensile strengths of both alloys were nearly the same. The reversals are attributed to strain-aging, and the superior strength of the commercial alloy at the lower temperatures is considered as being due to impurities restricting the mean free path of the flow units within the grains.

Increasing the speed of testing at $600^{\circ} \mathrm{F}$ tended to decrease the tensile strength of the high-purity alloy and to increase slightly the tensile strength of the commercial alloy. These observations are also consistent with the concept that the impurities, acting as barriers, tended to increase the resistance to flow of the commercial alloy at the higher speeds.

The effect of temperature on the fracture strength (see footnote 3 ) is shown in figure 9 . It should be pointed out that these values were affected by the necking characteristic (rim effect) of the alloys; the rim effect was more pronounced in the highpurity alloy than in the commercial alloy. The fracture strength of the high-purity alloy attained a maximum at $212^{\circ} \mathrm{F}$. At the usual speed of testing, the strength then decreased as the test temperature was increased up to $600^{\circ} \mathrm{F}$, increased slightly with a change in temperature from $600^{\circ}$ to $700^{\circ} \mathrm{F}$, and again decreased rapidly with further increase in temperature. The maximum fracture strength of the commercial alloy occurred at a higher temperature range $\left(300^{\circ}\right.$ to $\left.500^{\circ} \mathrm{F}\right)$, and then the general trend was about the same as for the high-purity alloy. At any selected test temperature below $1,100^{\circ} \dot{\mathrm{F}}$, the fracture strength of the high-purity alloy was higher than that of the commercial alloy. The fracture strength-temperature curves for the two alloys nearly coincide at temperatures ranging from $1,200^{\circ}$ to $1,700^{\circ} \mathrm{F}$.

Increasing the speed of testing from the normal to the intermediate rate used at $600^{\circ} \mathrm{F}$ (points B) resulted in raising the fracture strength of the commercial alloy, whereas the strength of the high-purity alloy was not materially affected by this change. However, the strength of the latter alloy increased markedly as the speed of testing was further increased (compare points B and C).

The relations between true stress and true strain at maximum load and at fracture are shown in figures 10 and 11, respectively. Strain-aging effects are again evident in the lower range of test temperatures. Although the trend was for the true strains at maximum load and at fracture to decrease as the true stresses decreased, and the temperatures were increased from $700^{\circ}$ to $1,500^{\circ} \mathrm{F}$ for the high-purity

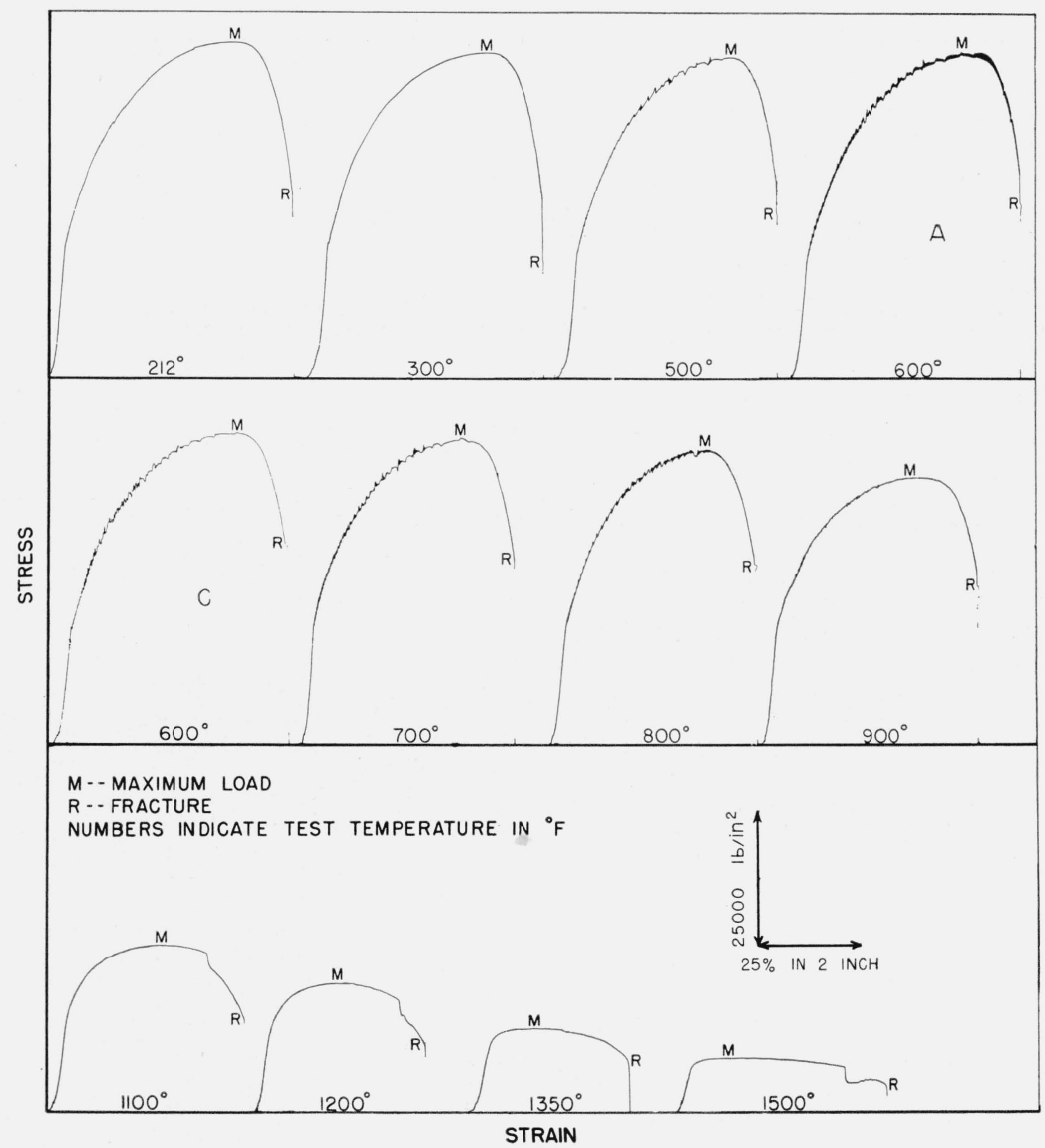

FIGURE 2. Autographic stress-strain curves for specimens of the high-purity alloy tested in tension at different temperatures. 
alloy and from $700^{\circ}$ to about $900^{\circ} \mathrm{F}$ for the commercial alloy, both curves for the latter alloy show reversals at a temperature of about $900^{\circ} \mathrm{F}$.

The values obtained for strain at maximum load and elongation and reduction of area (tables 2 and 3 ) were not significantly affected by variation in test temperature from about $75^{\circ}$ to $700^{\circ} \mathrm{F}$ (fig. 12); the values for strain and elongation for each alloy were somewhat higher at $75^{\circ} \mathrm{F}$ than the corresponding values at $212^{\circ} \mathrm{F}$. The minima obtained in the ductility-temperature curves for specimens of the commercial alloy at a temperature of about $900^{\circ} \mathrm{F}$ are associated with the brittle behavior of this alloy at this temperature.

Variations in the range of speed of testing used at $600^{\circ} \mathrm{F}$ had no material effect on the ductility of the alloys.

The results of hardness tests made at room temperature on the specimens fractured at different temperatures are summarized in figures 13 and 14 . The hardness increased continuously with the amount of deformation for the specimens of the high-purity alloy fractured at temperatures up to and including $1,000^{\circ} \mathrm{F}$ and also for the specimens of the commercial alloy at temperatures ranging from $75^{\circ}$ to $800^{\circ} \mathrm{F}$ (fig. 13). With a further increase in temperature to about $1,200^{\circ} \mathrm{F}$, the hardness at room temperature of each alloy was not significantly affected by the amount of plastic deformation. At test temperatures above $1,200^{\circ} \mathrm{F}$, the hardness generally decreased as the amount of deformation increased; no marked change in hardness occurred in the specimen of the high-purity alloy, tested at $1,500^{\circ} \mathrm{F}$ with change in reduction in area from about 20 to 42 percent. The hardness-reduction-in-area curves for the specimens tested at $600^{\circ} \mathrm{F}$ are at a somewhat higher level than those for specimens tested at lower or higher temperatures. The curves of figure 14 also show that the maximum hardness of each alloy was obtained in the specimens fractured at $600^{\circ} \mathrm{F}$. These curves (figs. 13 and 14) verify the fact that combination of strain-hardening and strain-aging predominated in the tensile tests carried out at temperatures ranging from about $75^{\circ}$ to $800^{\circ}$ or $1,000^{\circ} \mathrm{F}$, whereas recovery and recrystallization predominated at temperatures in excess of $1,200^{\circ} \mathrm{F}$.

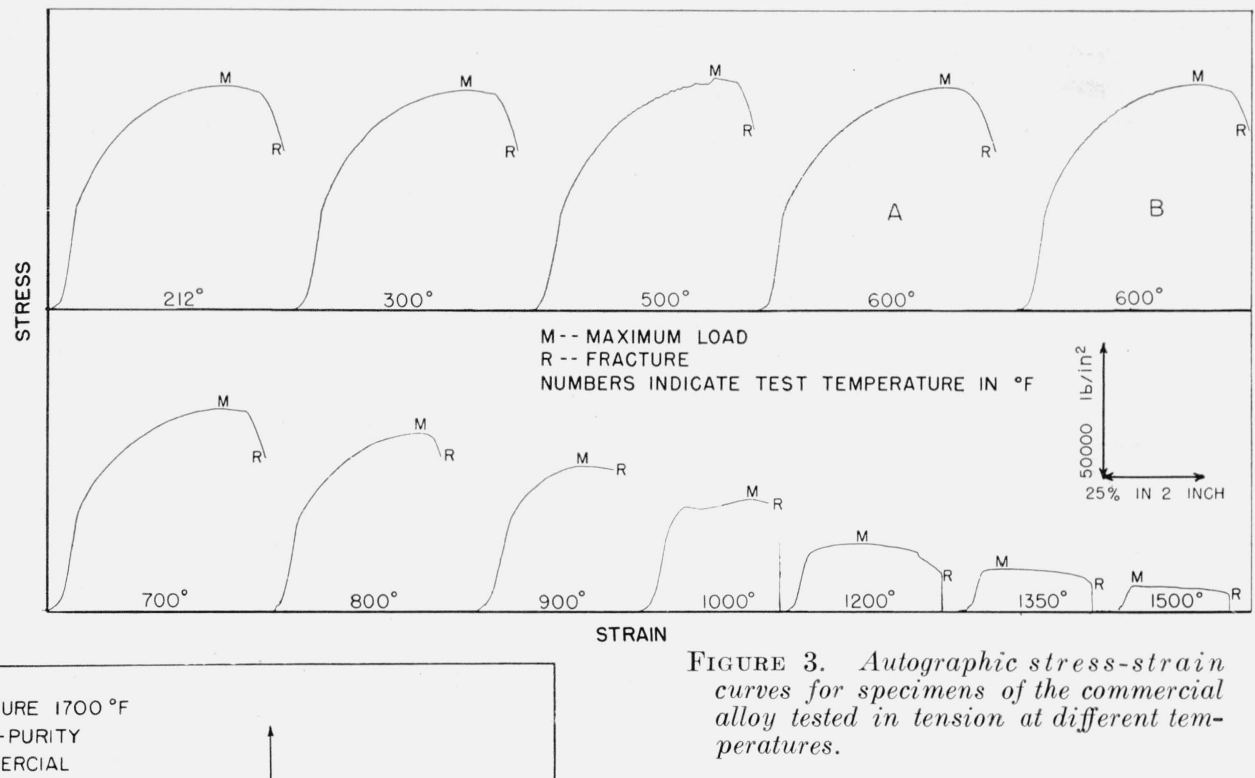

TEMPERATURE $1700^{\circ}$

A- - HIGH-PURITY

B- - COMMERCIAL

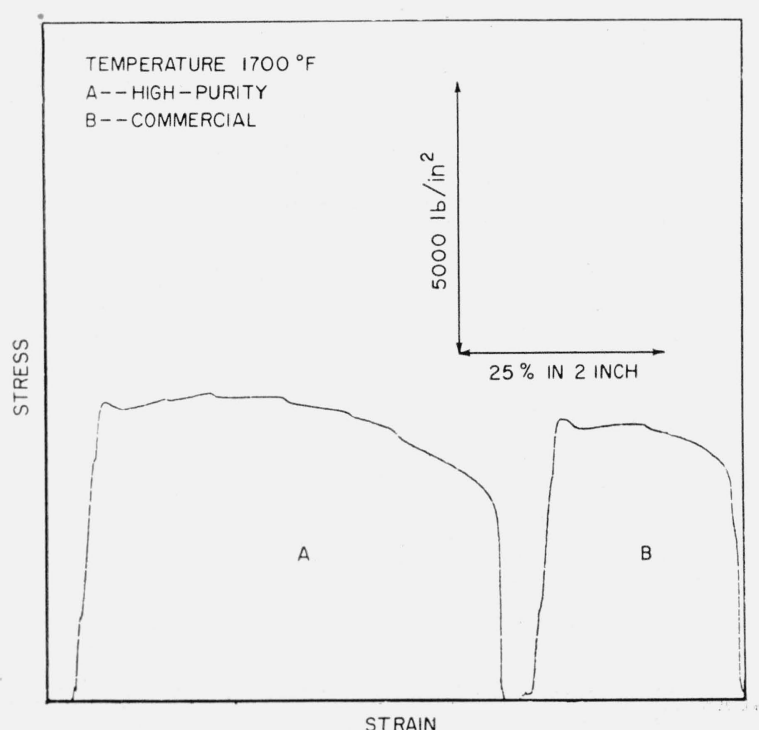

FIGURE 4. Autographic stress-strain curves for specimens tested in tension at $1,700^{\circ} \mathrm{F}$. 


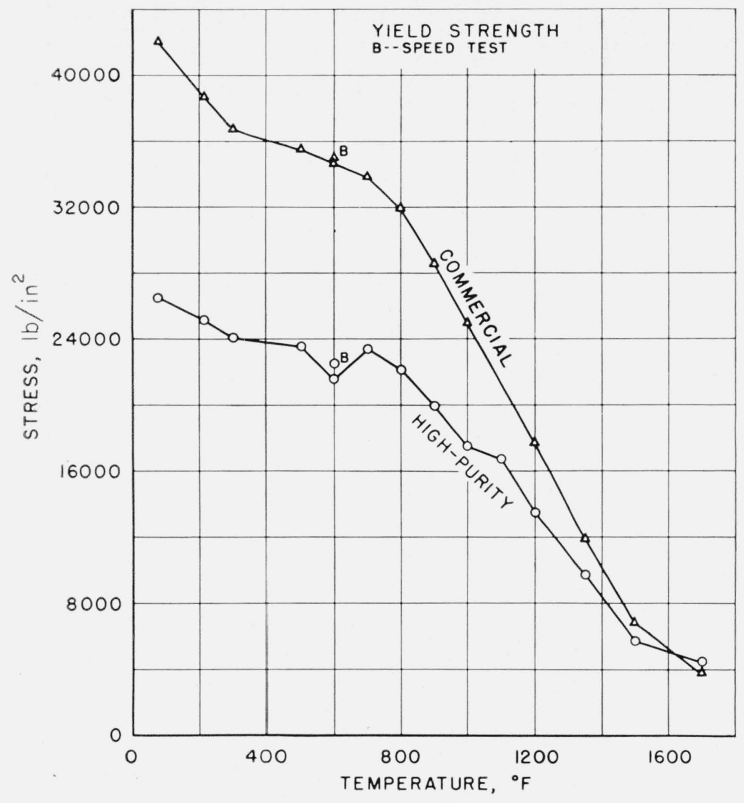

Figure 5. Influence of temperature on the yield strength $(0.2 \%$ off set $)$ of the alloys.

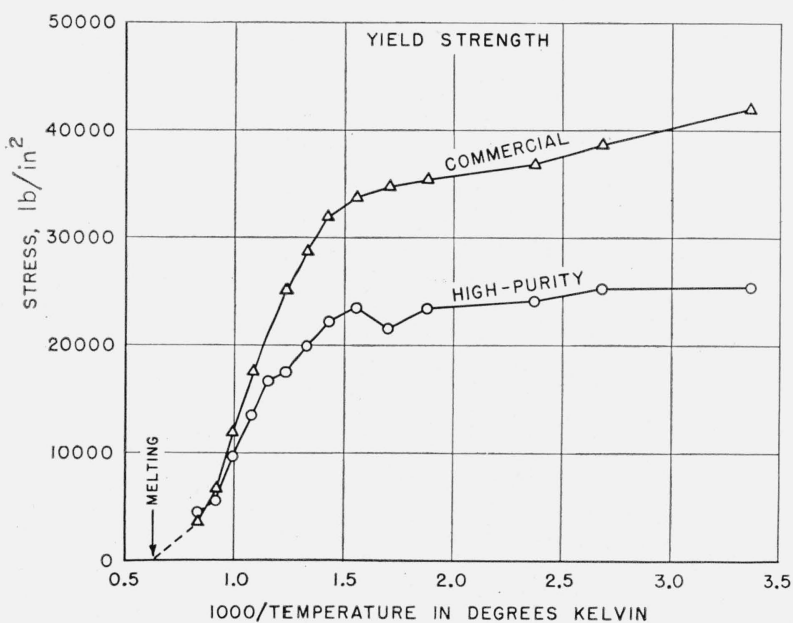

Figure 6. Relation between the yield strength $(0.2 \%$ offset) and the reciprocal of the temperature.

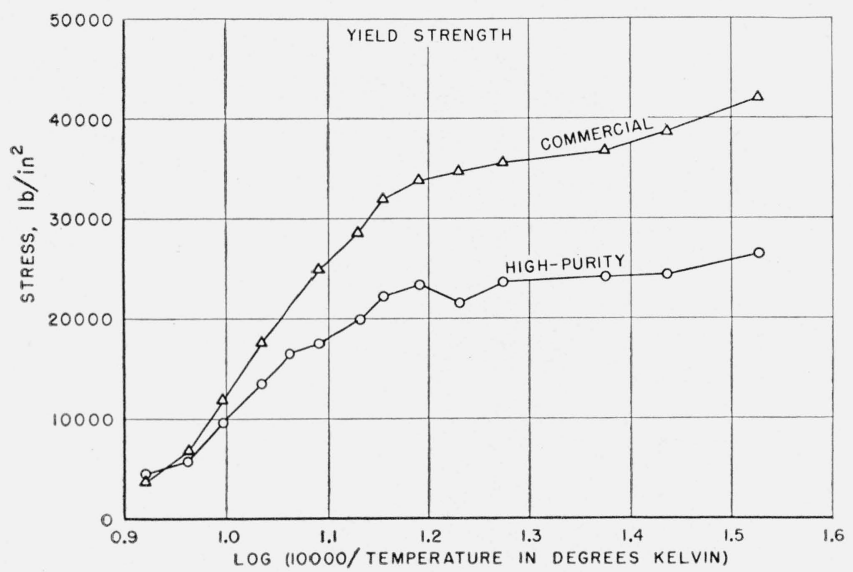

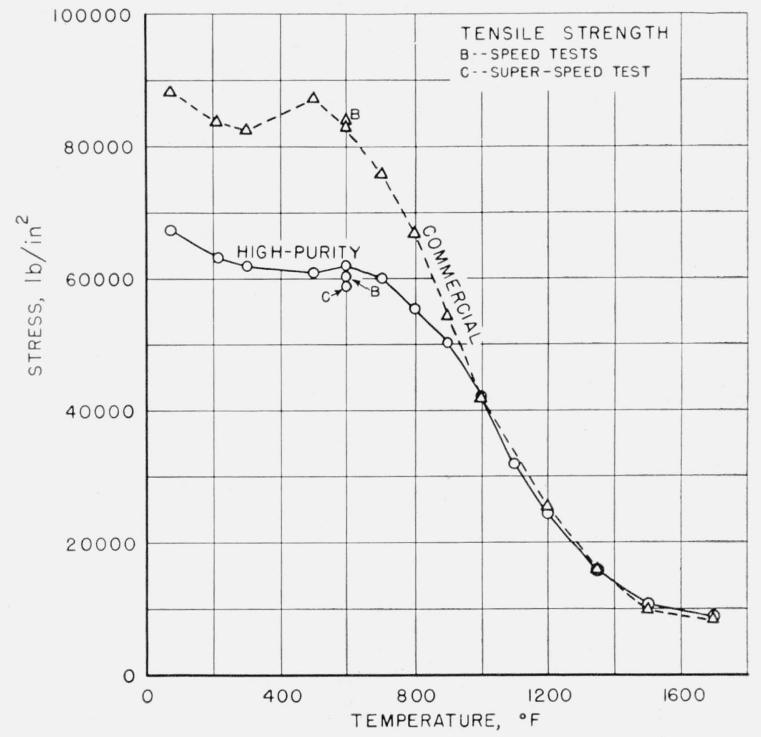

FIGURE 8. Influence of temperature on the tensile strength of the alloys.

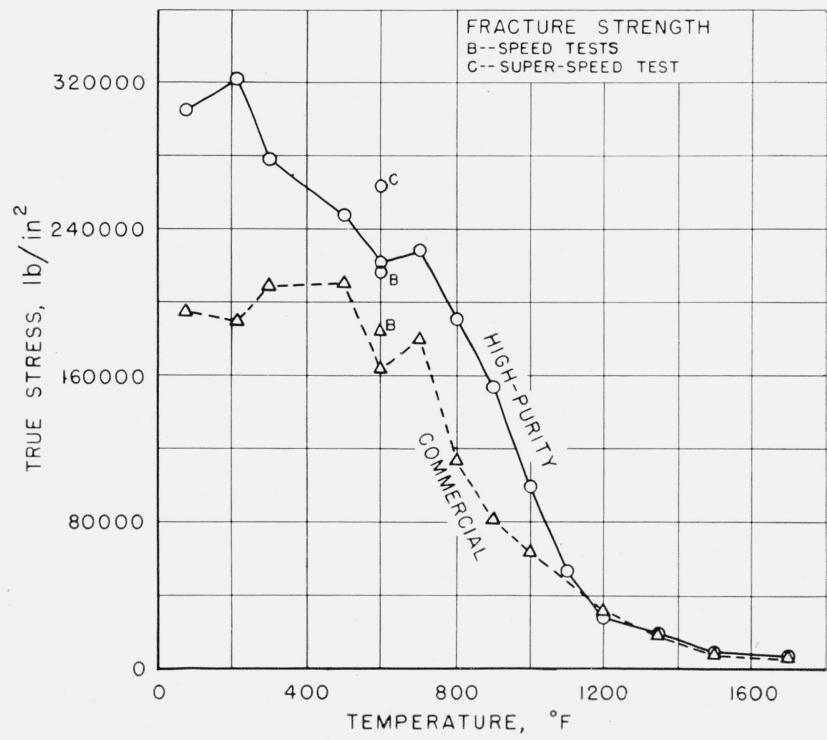

FigurE 9. Influence of temperature on the fracture strength of the alloys.
Figure 7. Relation between the yield strength (0.2\% offset) and logarithm of the reciprocal of the temperature. 


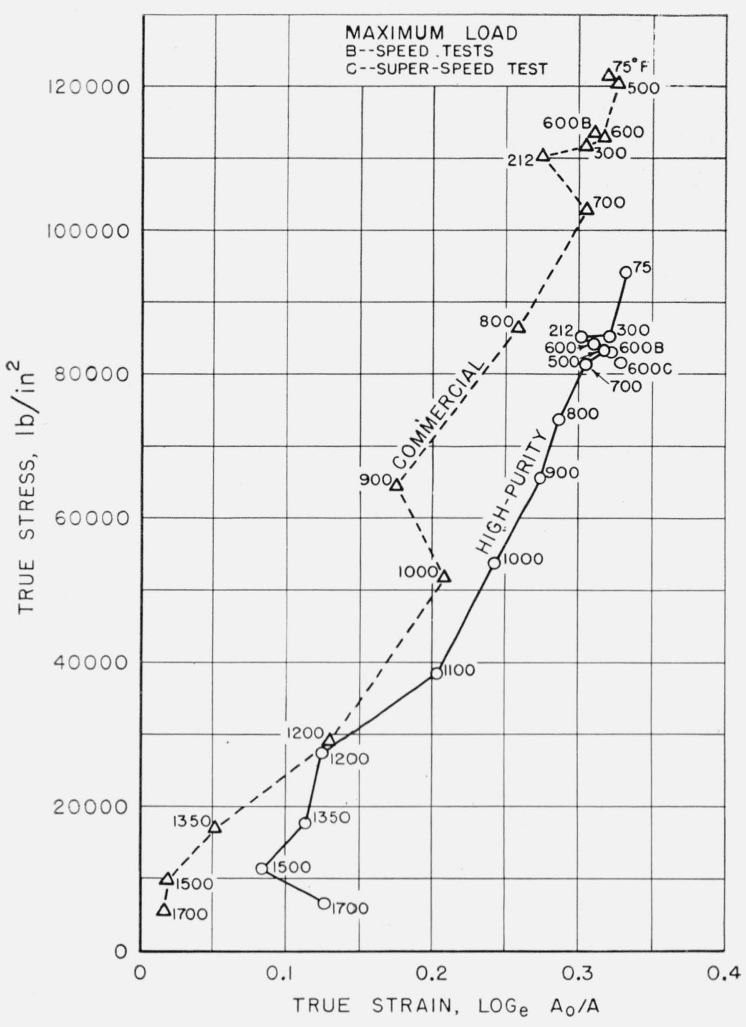

Figure 10. True stress-true strain relations at maximum load as affected by temperature and strain rate for the alloys.

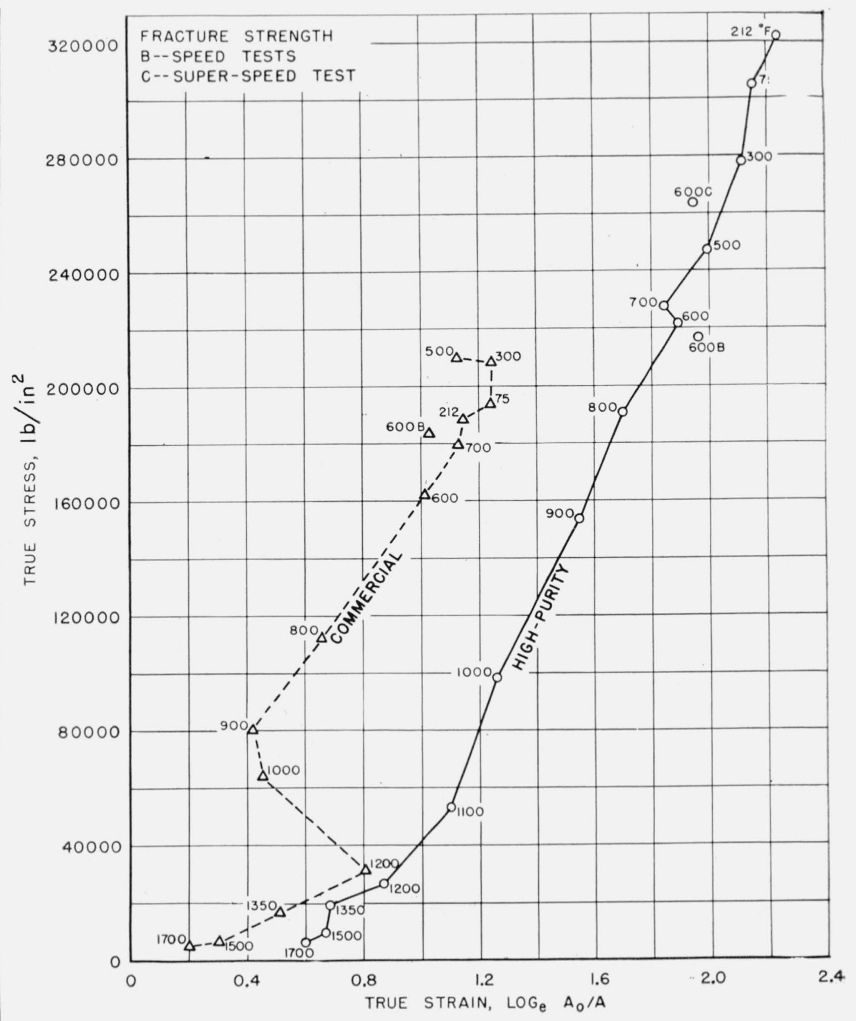

FIGURE 11. True stress-true strain relations at fracture as affected by temperature and strain rate for the alloys.

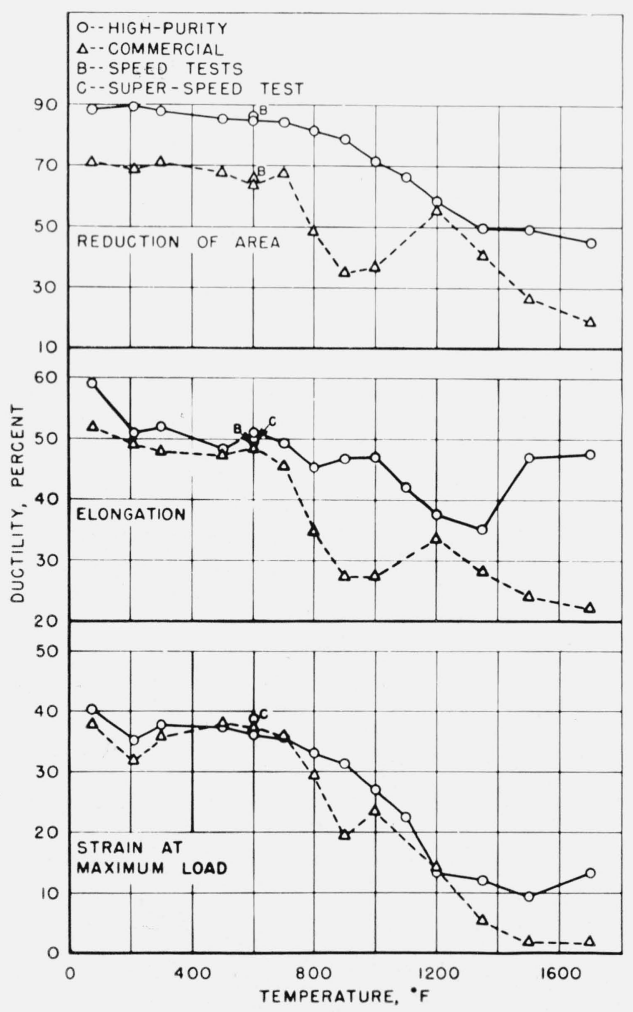

Figure 12. Influence of temperature on the ductility at maximum load and at fracture. 


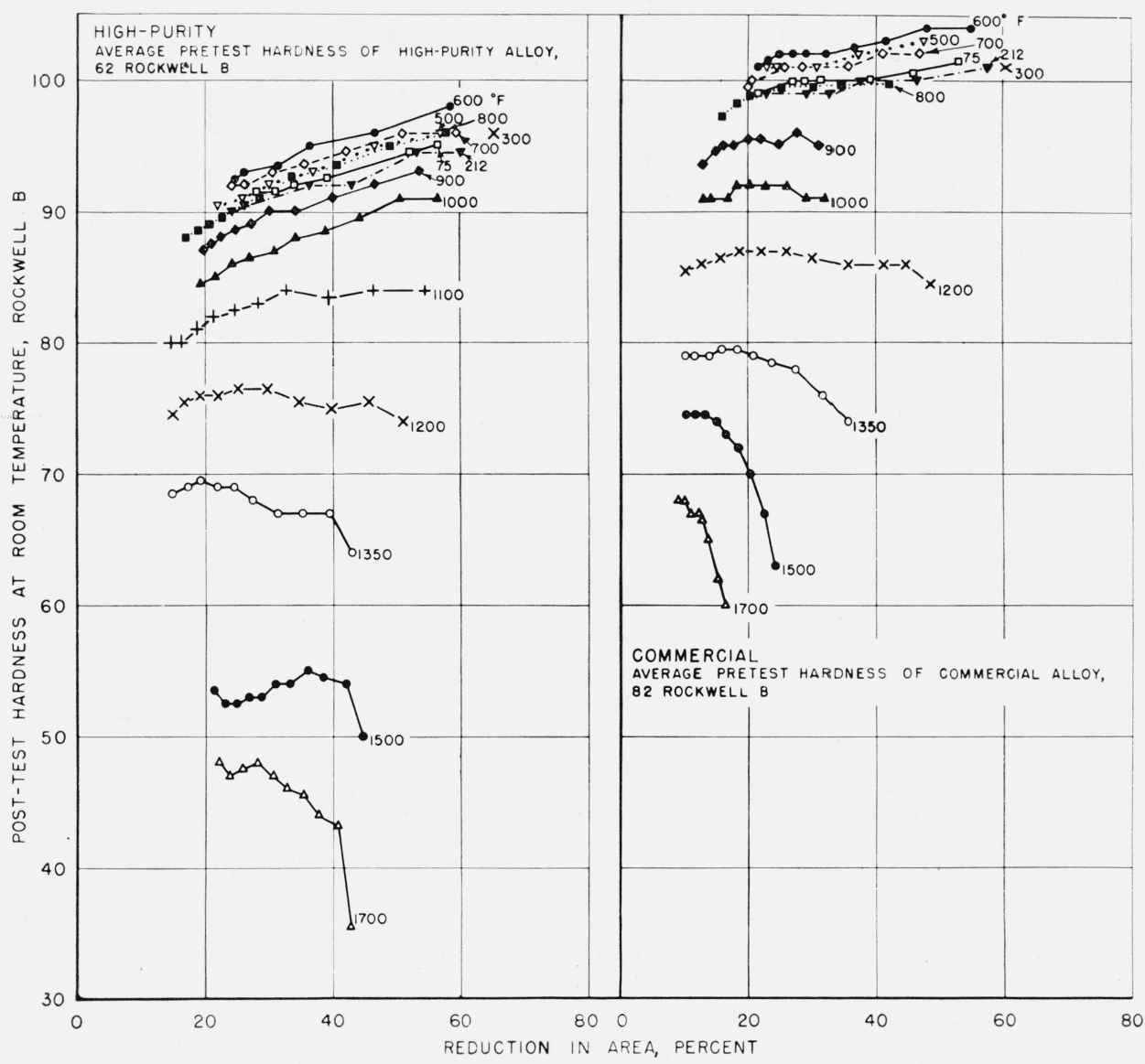

Figure 13. Influence of reduction in area at different temperatures on the hardness of the alloys at room temperature.

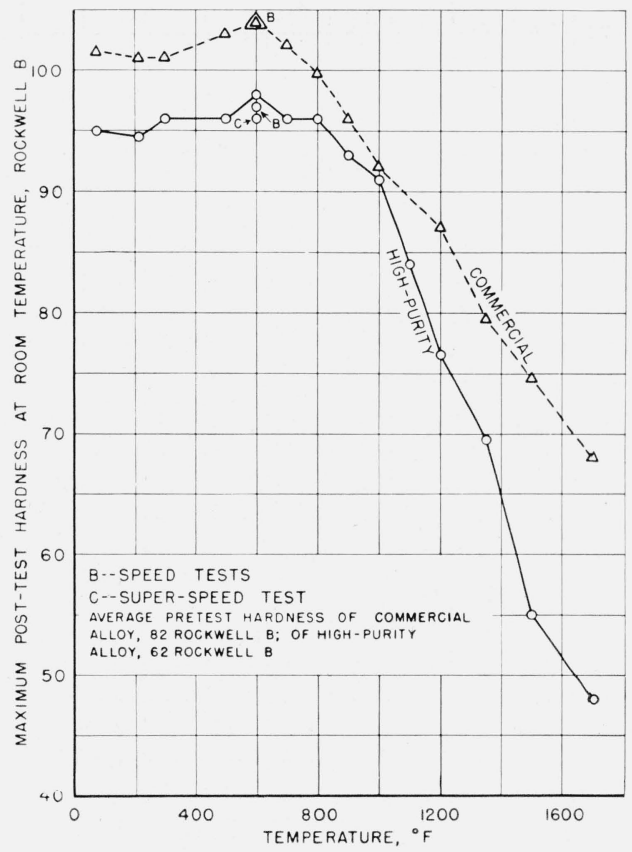

FIGURE 14. Influence of test temperature and strain rate, on the maximum hardness at room temperature of specimens of the alloys fractured in tension. 


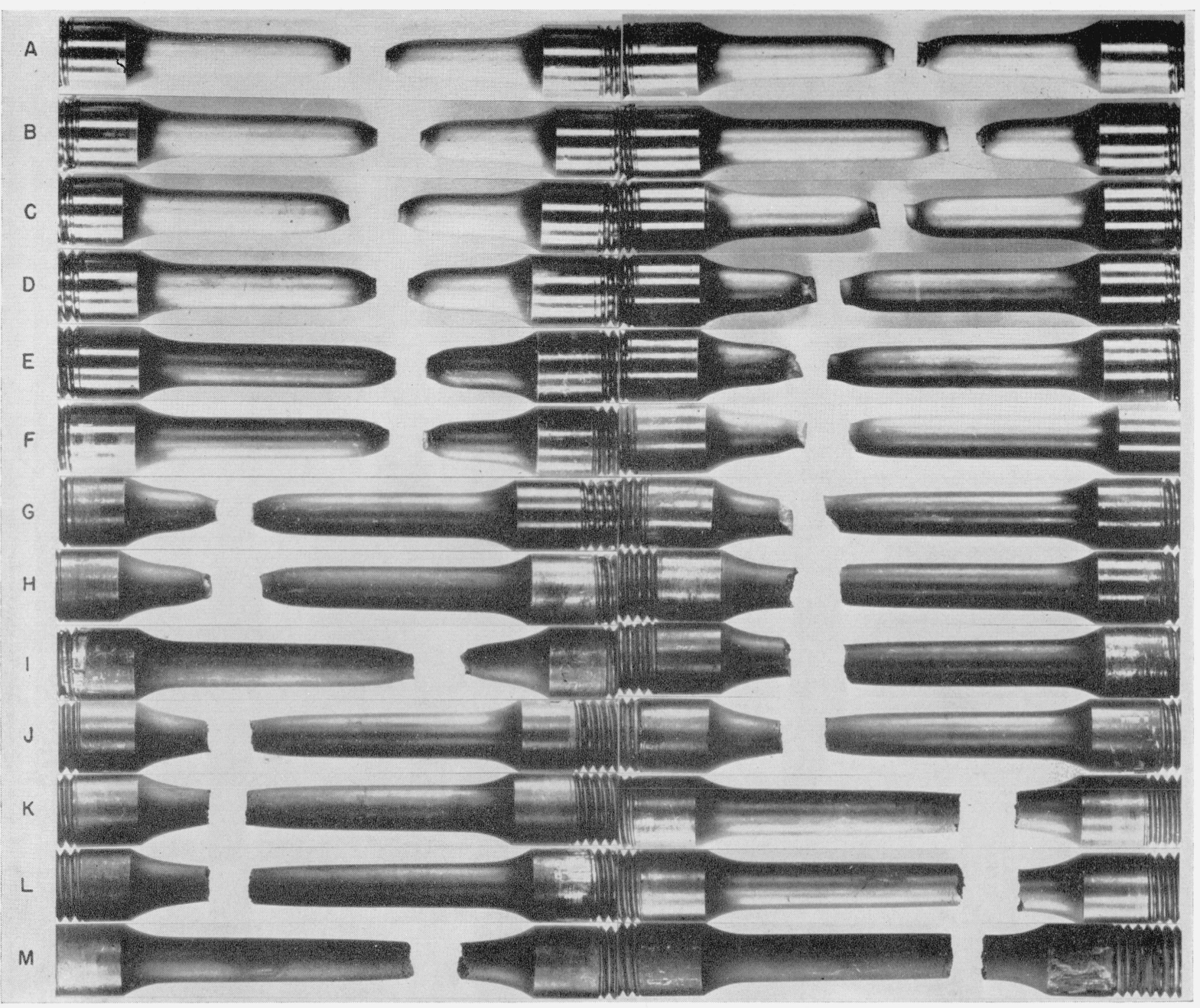

FigurE 15. Specimens fractured in tension at different temperatures.

Specimens of the high-purity alloy are shown at the left and specimens of the commercial alloy at the right of the photograph.
$\mathrm{A}, 75^{\circ} \mathrm{F} ; \mathrm{B}, 212^{\circ} \mathrm{F} ; \mathrm{C}, 300^{\circ} \mathrm{F} ; \mathrm{D}, 500^{\circ} \mathrm{F} ; \mathrm{E}, 600^{\circ} \mathrm{F} ; \mathrm{F}, 700^{\circ} \mathrm{F} ; \mathrm{G}, 800^{\circ} \mathrm{F} ; \mathrm{H}, 900^{\circ} \mathrm{F} ; \mathrm{I}, 1,000^{\circ} \mathrm{F} ; \mathrm{J}, 1,200^{\circ} \mathrm{F} ; \mathrm{K}, 1,350^{\circ} \mathrm{F} ; \mathrm{L}, 1,500^{\circ} \mathrm{F} ; \mathrm{M}_{1}, 700^{\circ} \mathrm{F}$. $\times 1 / 2$.

\subsection{Fracture Characteristics and Microstructures}

The effect of temperature on the tendency of the alloys to contract locally (neck) is illustrated by the photographs of the fractured specimens (fig. 15). At the lower range of temperature, specimens of both alloys contracted locally and fractured in a ductile manner with a relatively large rim effect (fig. 16). At the higher range of temperature, the specimens deformed more uniformly over the entire reduced section and fractured in a relatively brittle manner without a pronounced rim effect (figs. 15 and 16). However, the trend toward brittle behavior at the higher test temperatures was considerably more prominent for the commercial than for the high-purity alloy. This feature is also shown by a comparison of the curves of figure 17 . It is noteworthy that the reduction-in-area-distancefrom-fracture curve for the specimen of high-purity alloy tested at $1,700^{\circ} \mathrm{F}$ crosses all the curves for specimens of this alloy tested at lower temperatures.
This fact again illustrates the complexity of the mechanisms of flow and fracture of the allovs at elevated temperatures.

The appearance of the surface and the types of fractures obtained in the alloys tested at various temperatures are shown in figure 18. No surface cracking was observed in any of the specimens of the highpurity alloy tested at temperatures up to and including $900^{\circ} \mathrm{F}$ (fig. 18,D); shear-type fractures and circumferential strain markings were characteristic of these specimens. Except for fewer strain markings, these characteristics were also obtained in specimens of the commercial alloy fractured at temperatures up to and including $800^{\circ} \mathrm{F}$ (fig. 18, A and B). Surface cracks were observed in all of the specimens fractured at the higher temperatures, and the brittleness increased with temperatures (fig. $18, \mathrm{D}$ and $\mathrm{E}, \mathrm{C}$ and $\mathrm{F}$ ); the surface appearance was similar for the specimens of both alloys fractured at $1,200^{\circ} \mathrm{F}$ (not shown). Thus, the tendency toward brittle behavior was accentuated by the in- 
creased amount of impurities and by an increase in test temperatures.

The influences of temperature on the microstructures and on internal cracking of the specimens are illustrated in figures 19 to 22 , inclusive.

The initially equiaxed grains of the annealed alloys (fig. 19, $\mathrm{A}$ and B) were elongated in the direction of the applied stresses in the specimens fractured at temperatures below the recrystallization range (fig. 19); the extent of the elongation apparently decreased as the temperature was increased. The microcracks were confined to the region of complete fracture in the specimens of the high-purity alloy tested at temperatures up to and including $900^{\circ} \mathrm{F}$ (fig. 19,C and E) and in the specimens of the commercial alloy tested at temperatures up to $600^{\circ} \mathrm{F}$ (fig. 19,D). Appreciable microcracking, extending from the axis to the surface, occurred in the specimen of the commercial alloy fractured at $900^{\circ} \mathrm{F}$ (fig. $19, \mathrm{~F}$ and $\mathrm{H}$ ). The formation of an oxide film (top edge of the photomicrograph of fig. 19,H) may have also contributed to the brittle behavior of this specimen.

Numerous microcracks were observed both in the region of fracture and at some distance from it in all the specimens fractured at temperatures in ex- cess of the recrystallization temperatures (figs. 20, 21 , and 22). The number of these cracks and the extent of cracking, however, varied with the temperature, composition of the alloy, and distance from the region of complete fracture. At $1,200^{\circ} \mathrm{F}$, the two alloys were nearly alike with regard to cracking (fig. 20, $\mathrm{A}$ and B ; fig. 22,A and B), and no detectable grain growth occurred.

At $1,500^{\circ} \mathrm{F}$, the microcracks observed in the region of fracture were possibly somewhat less numerous but of larger size in the specimen of the high-purity alloy than in the specimen of the commercial alloy (fig. 20,C and D; fig. 21,A and B). This was true also in the region about 0.5 in. from the fracture (fig. 22,C and D.) The microcracking was confined principally to the grain boundaries, and no abnormal grain growth was detected in the recrystallized structure.

At $1,700^{\circ} \mathrm{F}$, intercrystalline cracking was prominent in the vicinity of fracture and as some distance from fracture in the specimens of both alloys (fig. 20,E and F ; fig. 21,C and D; fig. 22,E and F). Strain markings and twins were present in the recrstallized structures at the time of failure. Appreciable grain growth also occurred at this temperature.
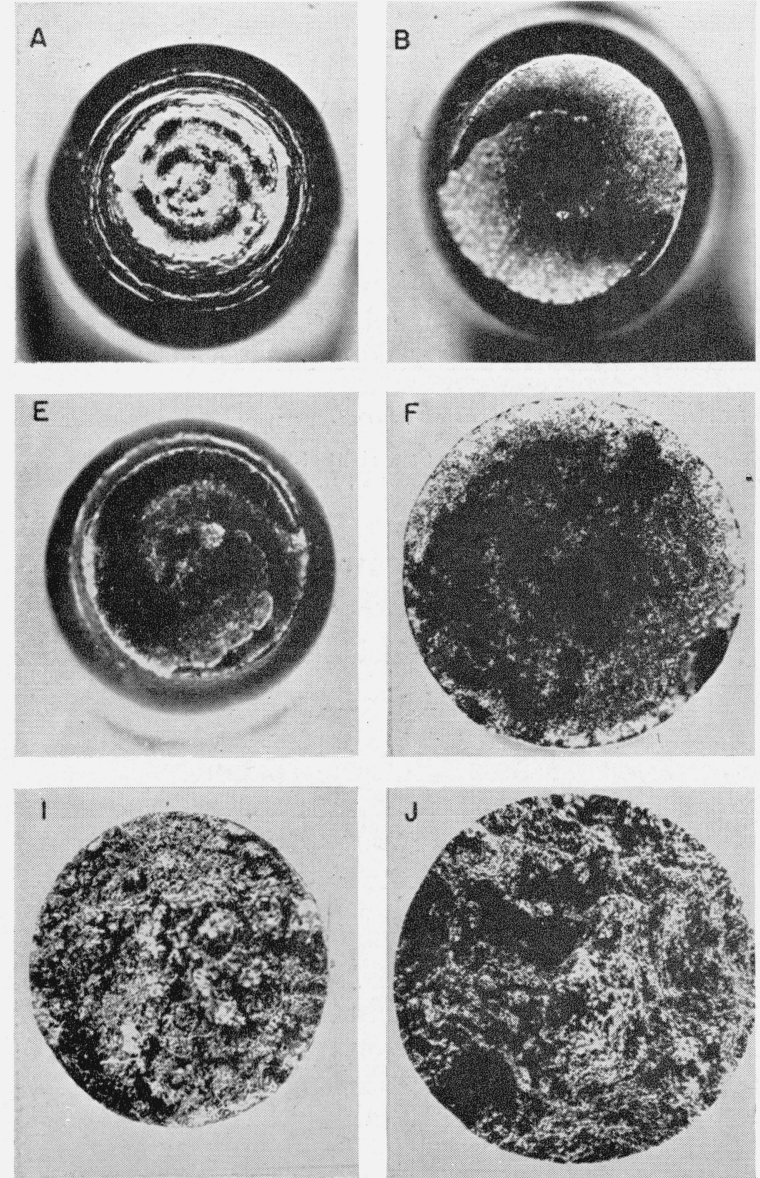
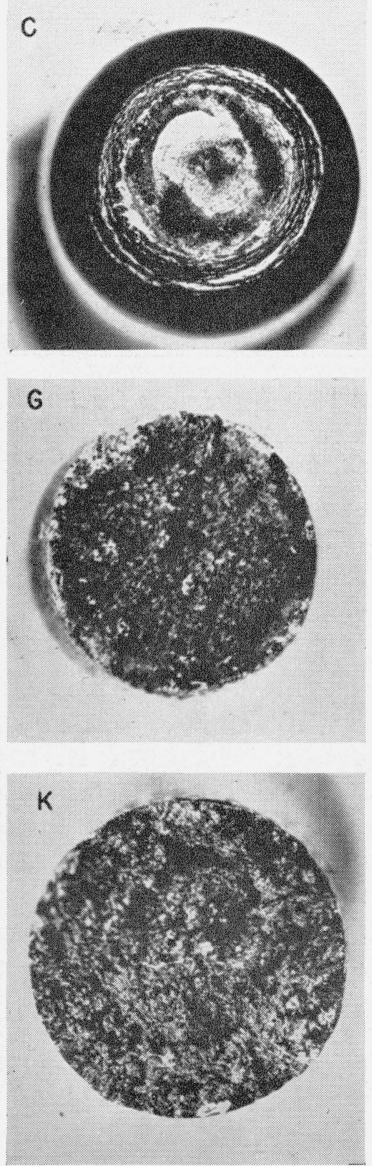
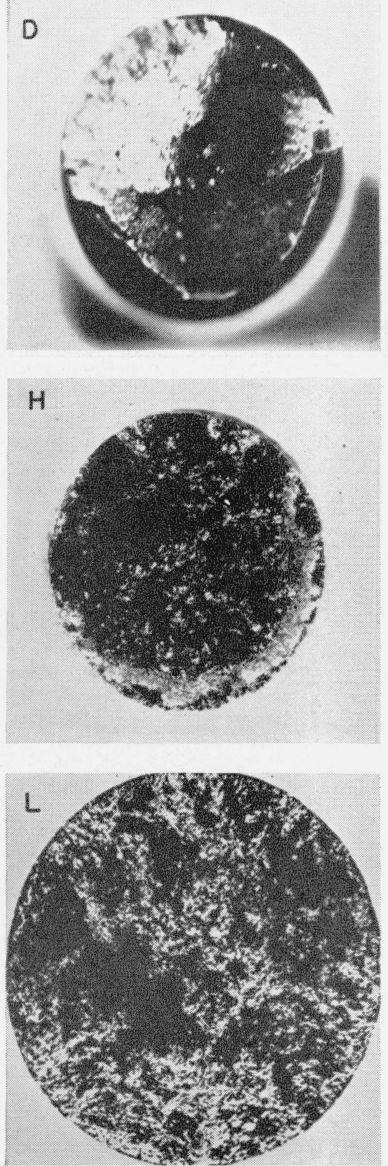

Figure 16. Cross sections at fracture of specimens of the alloys fractured in tension at different temperatures. A, C, E, G, I, and K, Specimens cf the high-purity alloy; B, D, F, H, and L, specimens of the commercial alloy. A, B, $300^{\circ} \mathrm{F} ; \mathrm{C}, \mathrm{D}, 600^{\circ} \mathrm{F} ; \mathrm{E}, \mathrm{F}$,
$900^{\circ} \mathrm{F} ; \mathrm{G}, \mathrm{H}, 1,200^{\circ} \mathrm{F} ; \mathrm{I}, \mathrm{J}, 1,500^{\circ} \mathrm{F} ; \mathrm{K}, \mathrm{L}, 1,700^{\circ} \mathrm{F}$. $\times 3.5$. 


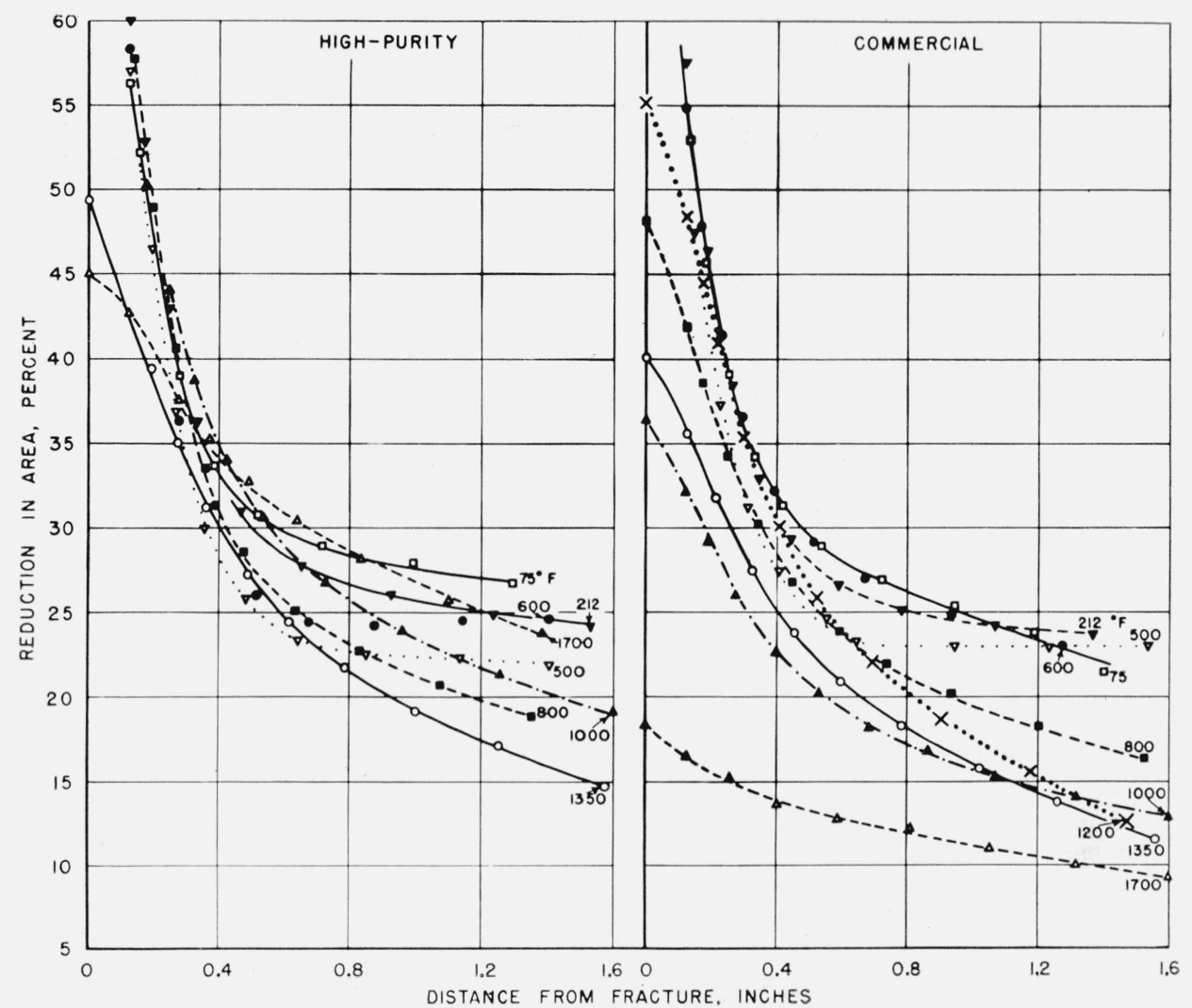

Figure 17. Plastic deformation of the specimens fractured in tension at different temperatures.
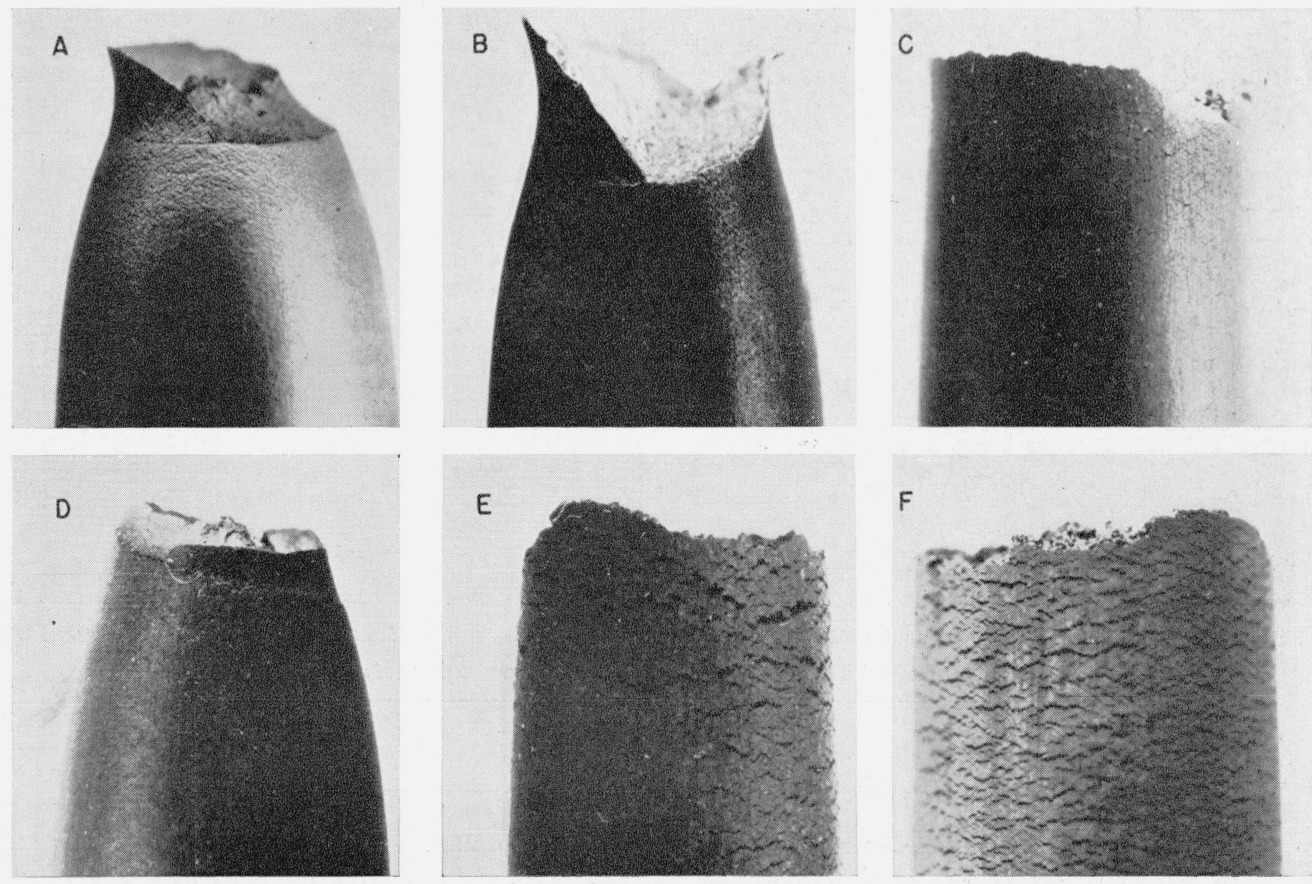

FIGURE 18. Influence of test temperature on the appearance of the surface of the specimens at fracture. A, B, C, and F, specimens of the commercial alloy; D and E, specimens of the high-purity alloy. A, $300^{\circ} \mathrm{F} ; \mathrm{B}, 600^{\circ} \mathrm{F} ; \mathrm{C}, \mathrm{D}$,
$900^{\circ} \mathrm{F} ; \mathrm{E}, \mathrm{F}, 1,700^{\circ} \mathrm{F}, \times 3.5$. 


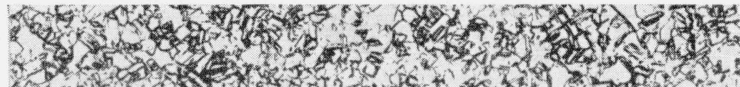

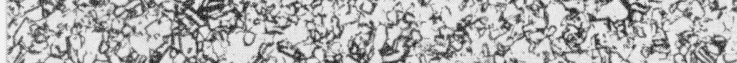
-

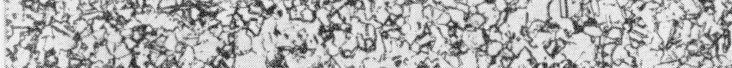

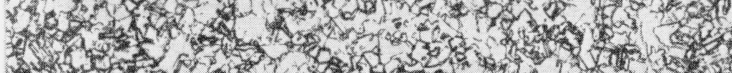

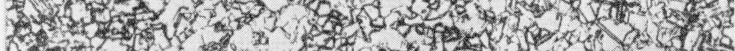
L. 3. 3 . 3 .

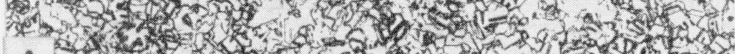
A 3 A
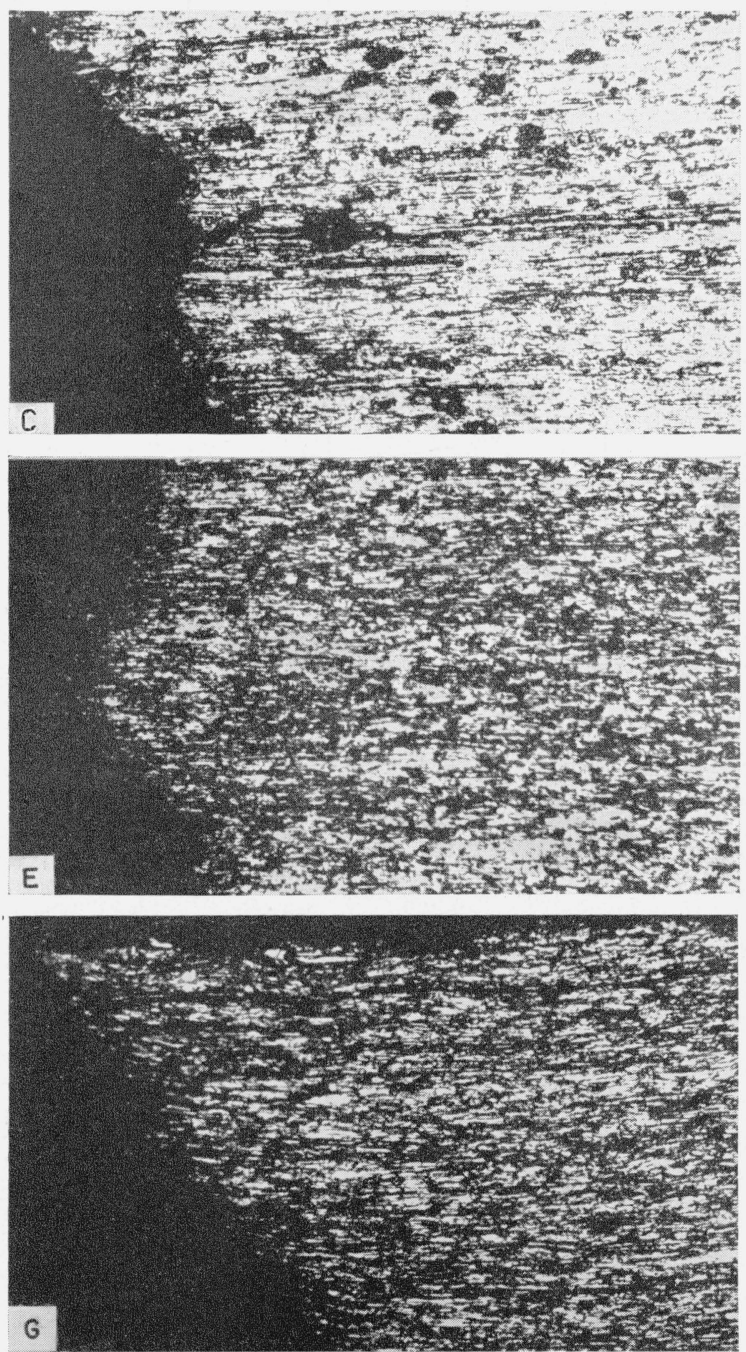

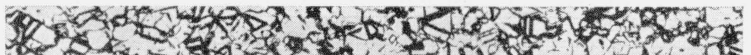
1.

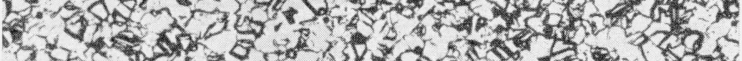

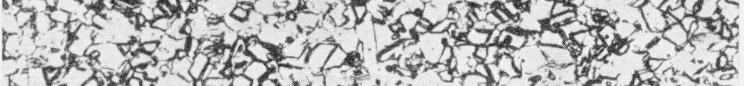

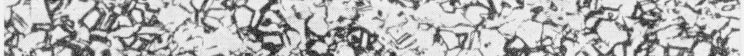

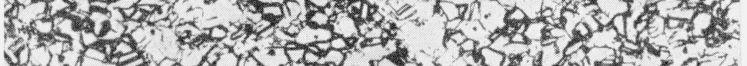

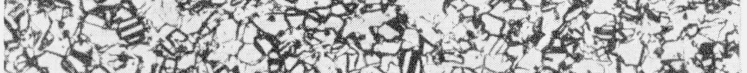

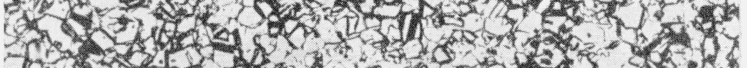

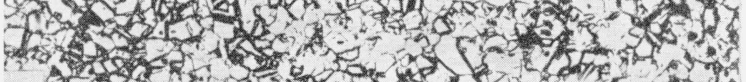

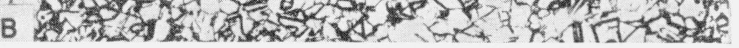
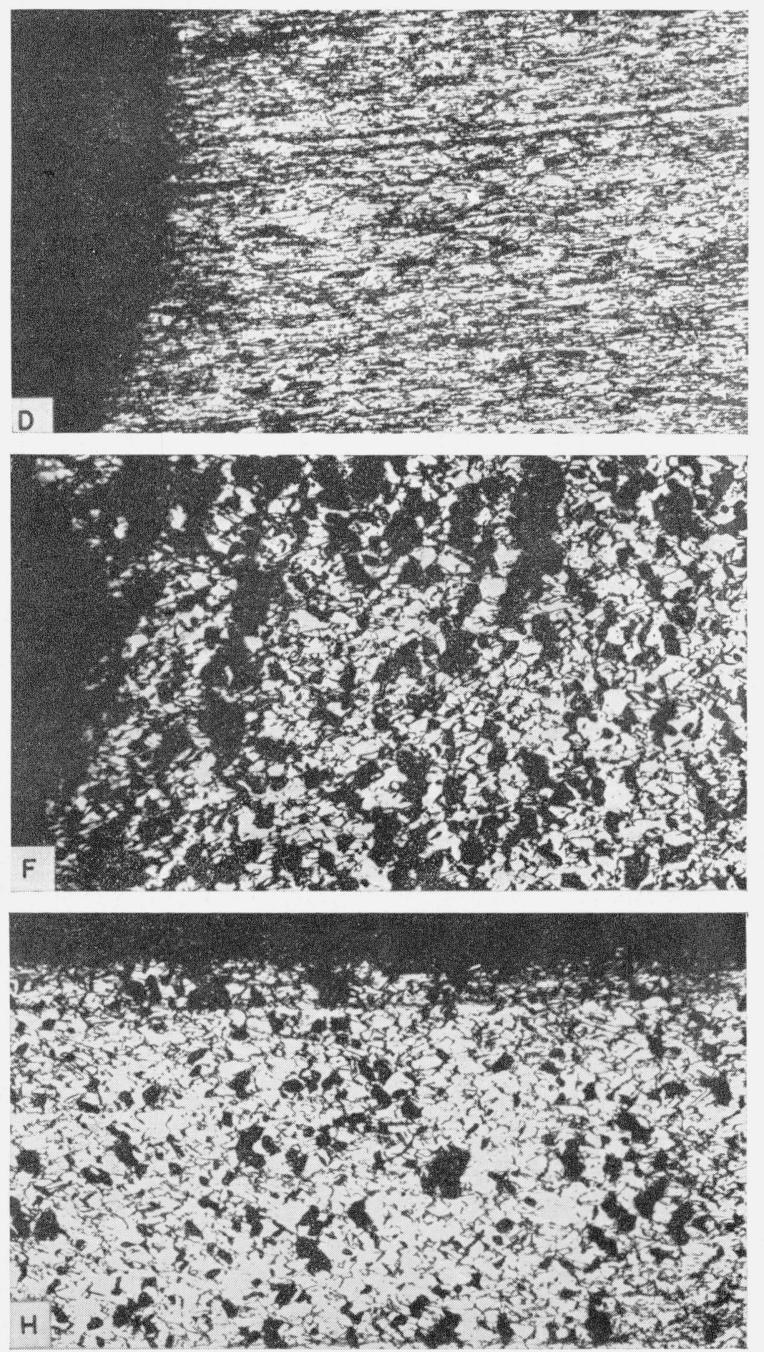

FIGURE 19. Structure of the alloys as annealed and after fracturing in tension at different temperatures. Longitudinal section etched with 6 parts of nitric (concentrated) and 4 parts of glacial acetic acids. $\times 75$.

\begin{tabular}{|c|c|c|c|}
\hline & Alloy & $\begin{array}{l}\text { Test tem- } \\
\text { perature }\end{array}$ & Remarks \\
\hline $\begin{array}{l}\mathrm{A} \\
\mathrm{B}_{-} \\
\mathrm{C} \\
\mathrm{D} \\
\mathrm{E} \\
\mathrm{F} \\
\mathrm{F} \\
\mathrm{G} \\
\mathrm{H}_{-}\end{array}$ & 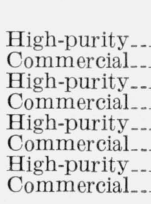 & $\begin{array}{l}\circ F \\
\text { None } \\
\text { None } \\
600 \\
600 \\
900 \\
900 \\
900 \\
900\end{array}$ & $\begin{array}{l}\text { As annealed. } \\
\text { Do. } \\
\text { Structure near axis at fracture. } \\
\text { Do. } \\
\text { Do. } \\
\text { Do. } \\
\text { Structure near surface at fracture. } \\
\text { Do. }\end{array}$ \\
\hline
\end{tabular}



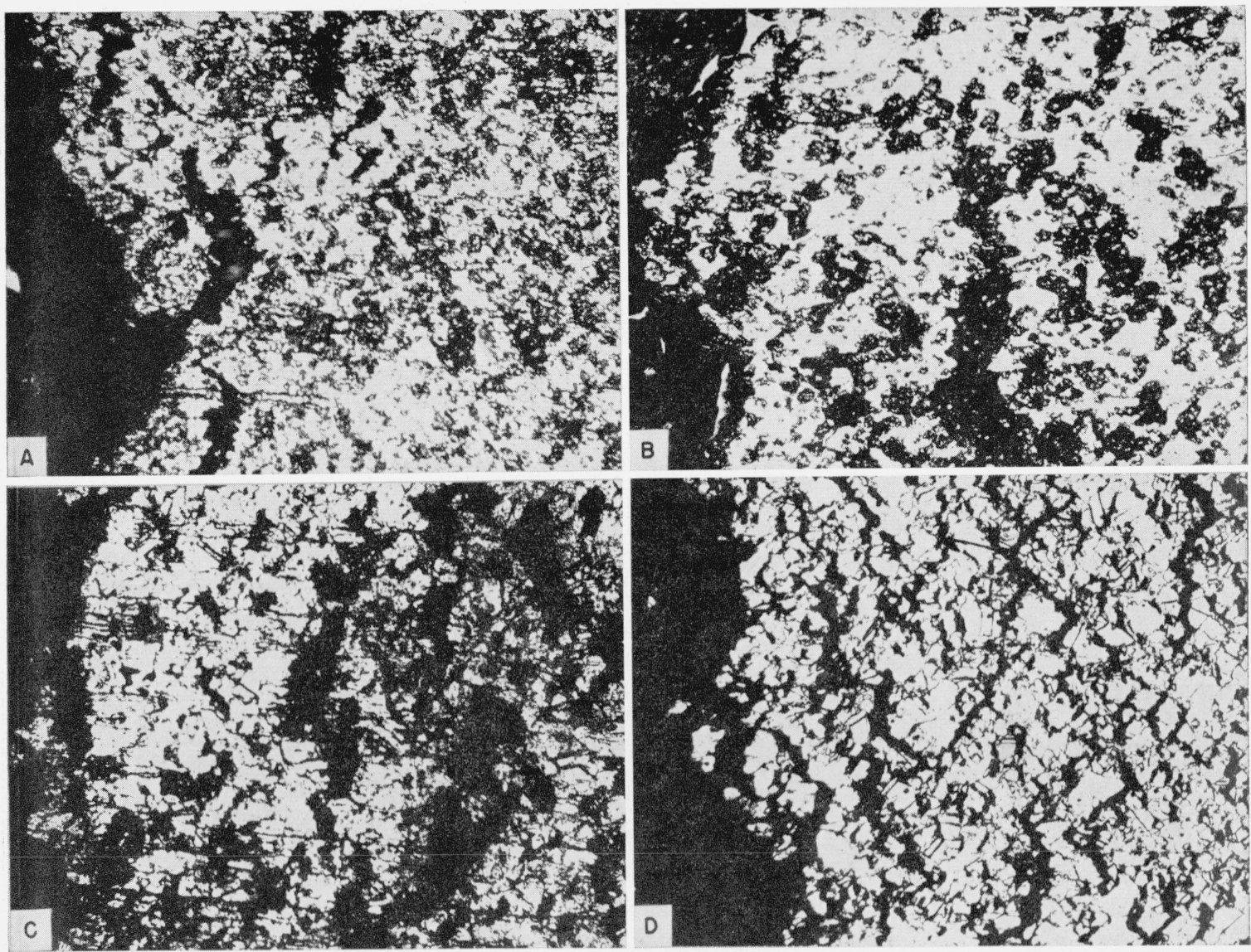

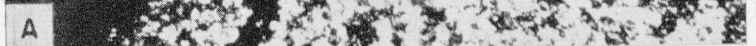

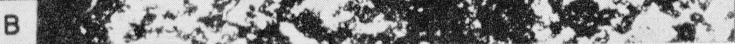

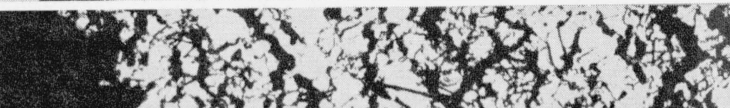

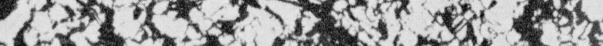

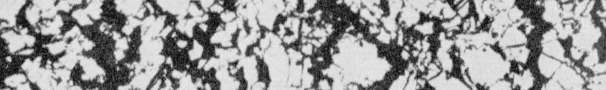

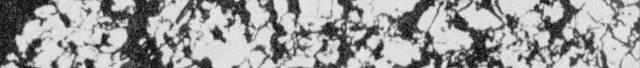

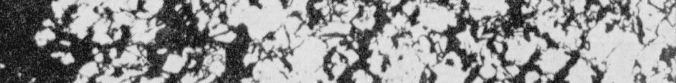

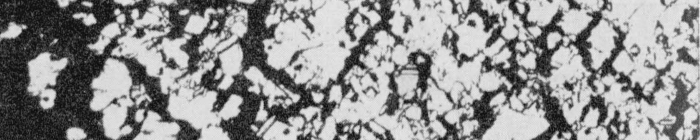

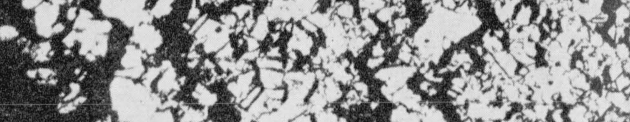
300.20230

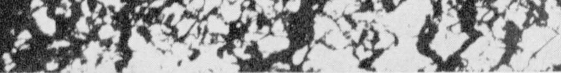

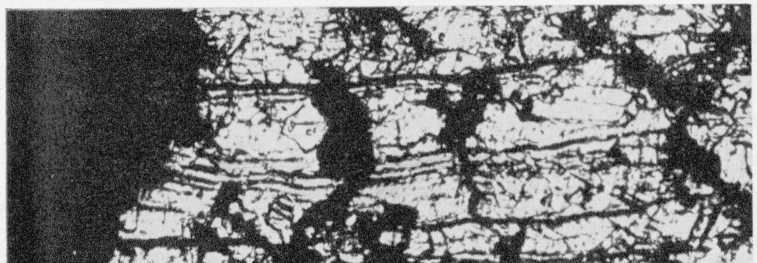

(2) 231038

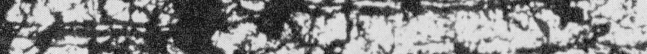

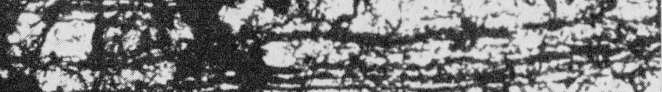

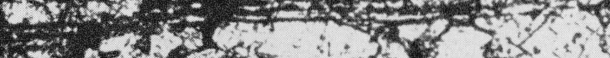

1.2. teras

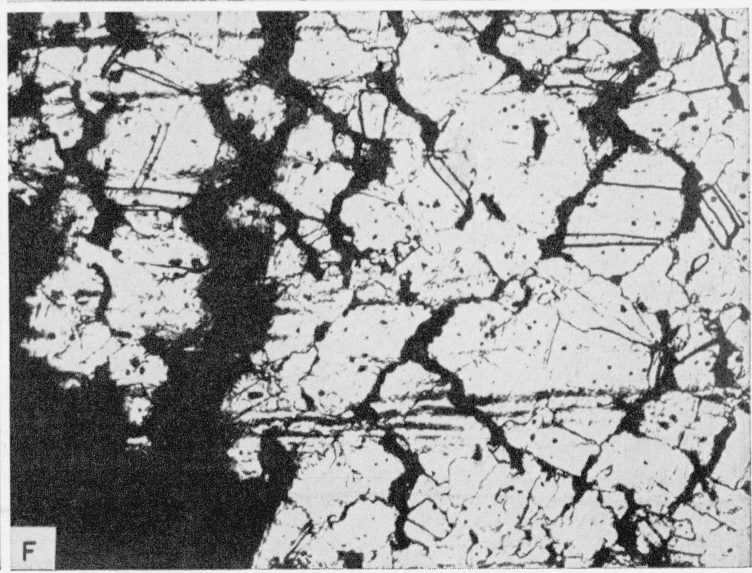

E:

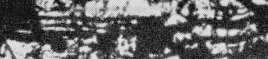

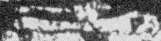

FIGURE 20. Structure of the alloys after fracturing in tension at different temperatures above the recrystallization ranges.

Longitudinal sections etched with 6 parts of nitric (concentrated) and 4 parts of glacial acetic acids. $\times 75$.

\begin{tabular}{|c|c|c|c|}
\hline & Alloy & $\begin{array}{l}\text { Test tem- } \\
\text { perature }\end{array}$ & Remarks \\
\hline $\begin{array}{l}\mathrm{A} \ldots \ldots \ldots \\
\mathrm{B} \\
\mathrm{C} \\
\mathrm{D} \\
\mathrm{E}\end{array}$ & 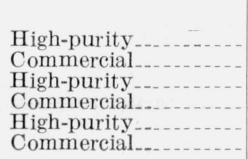 & $\begin{array}{l}{ }^{\circ} \\
1,200 \\
1,200 \\
1,500 \\
1,500 \\
1,700 \\
1,700\end{array}$ & $\begin{array}{l}\text { Structure near axis at fracture. } \\
\text { Do. } \\
\text { Do. } \\
\text { Do. } \\
\text { Do. } \\
\text { Do. }\end{array}$ \\
\hline
\end{tabular}




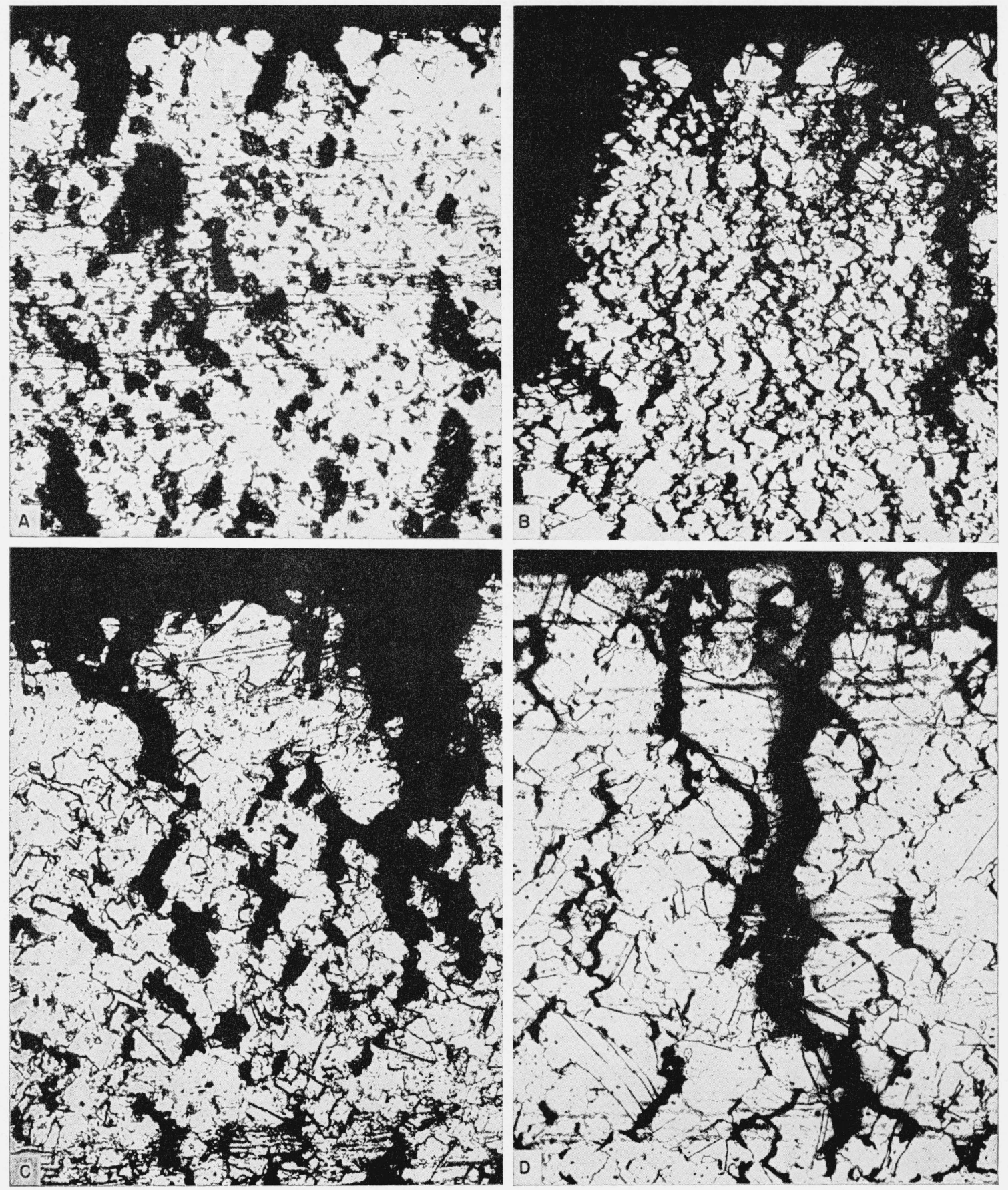

Figure 21. Structure of the alloys after fracturing in tension at $1,500^{\circ}$ or $1,700^{\circ} \mathrm{F}$.

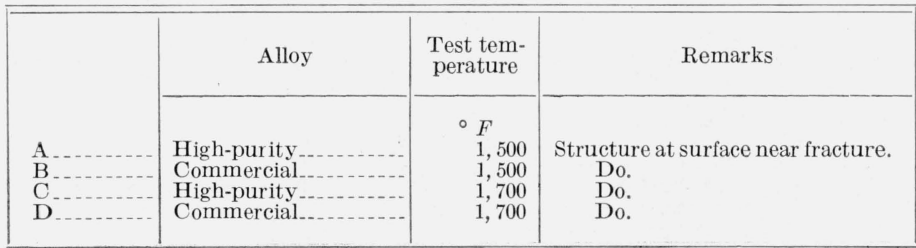



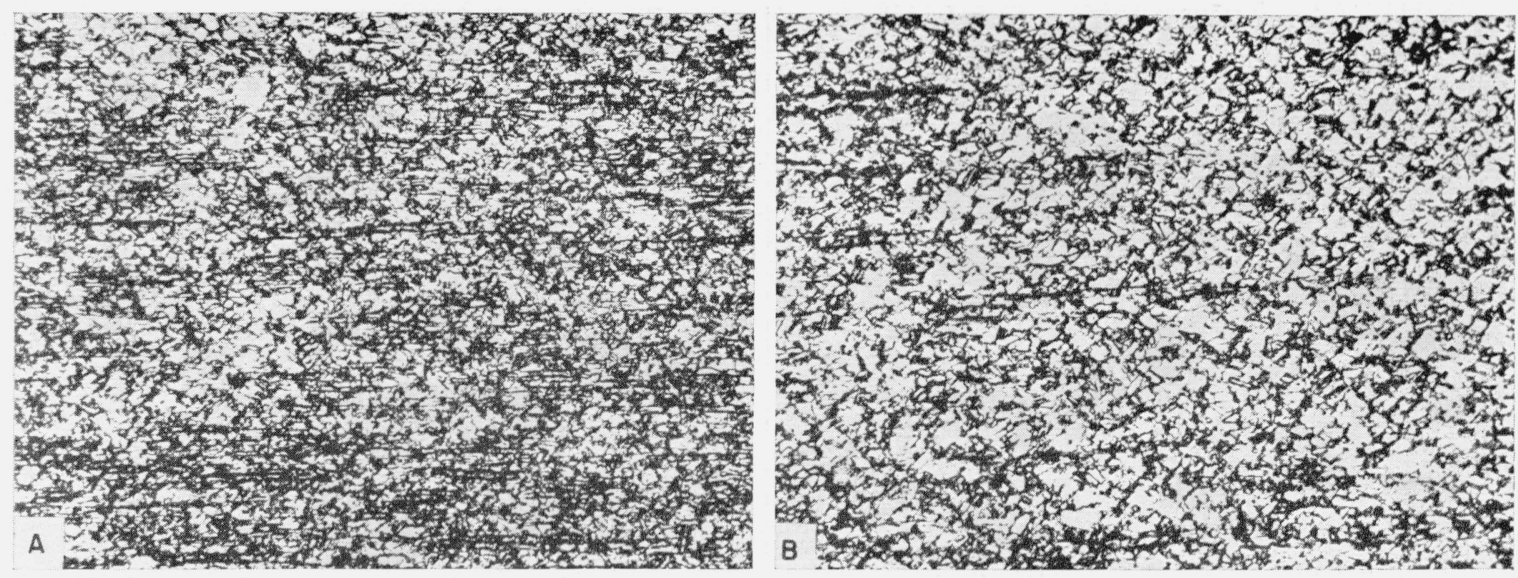

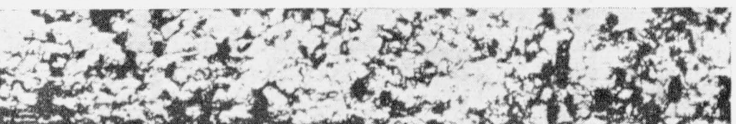

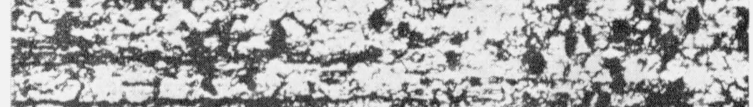

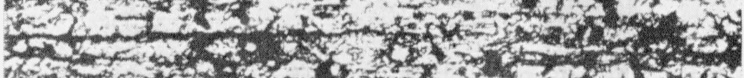
3.

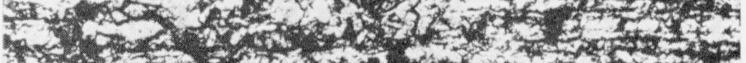

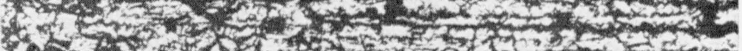

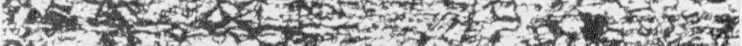

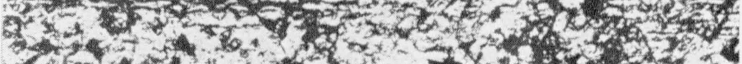

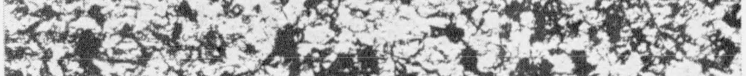
T.

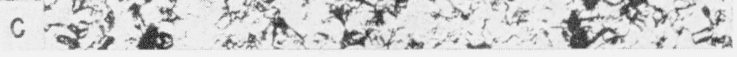
2.

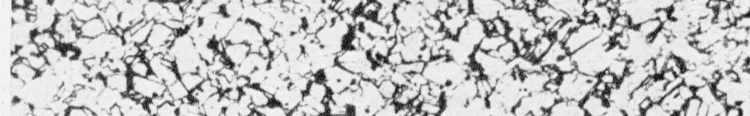

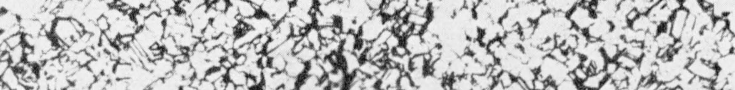

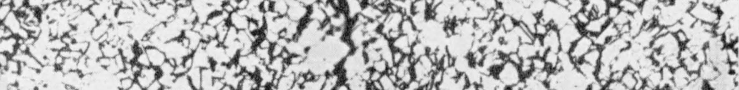

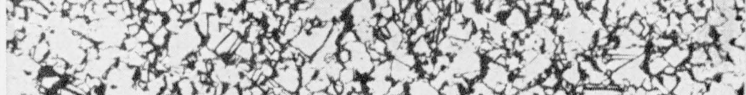

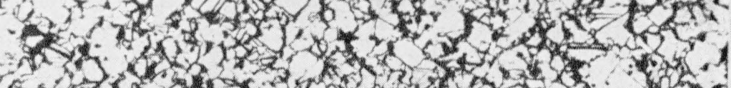

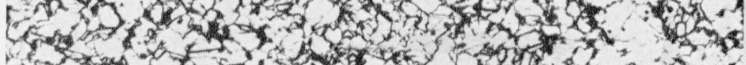
(16)

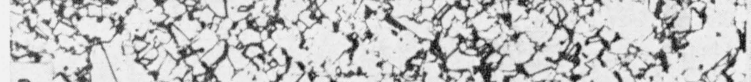
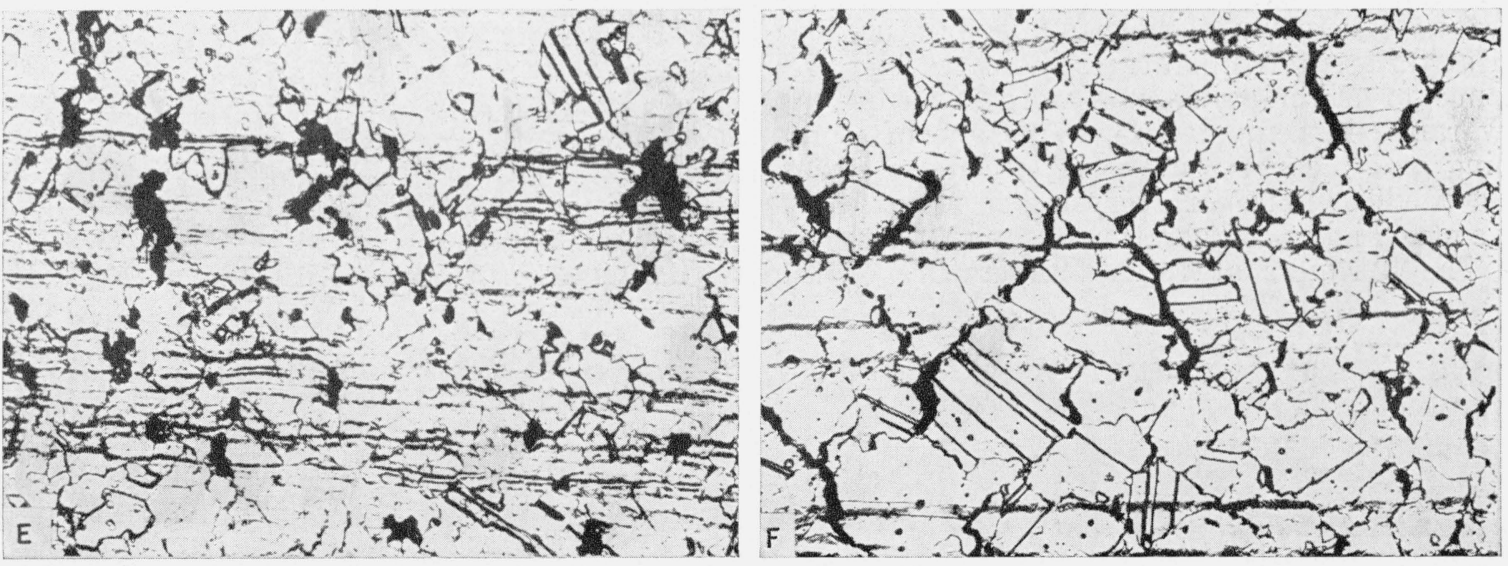

FIGURE 22. Structure of the alloys after fracturing in tension at different temperatures above the recrystallization ranges.

Longitudinal sections etched with 6 parts of nitric (concentrated) and 4 parts of glacial acetic acids. $\times 75$

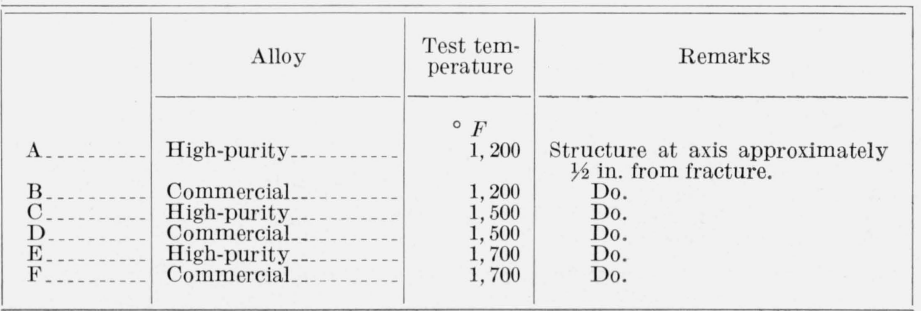




\section{Summary}

Tensile tests were made at temperatures ranging from $75^{\circ}$ to $1,700^{\circ} \mathrm{F}$ on specimens of both high-purity and commercial 70-percent-nickel-30-percent-copper alloys, each with the same initial grain size and structure.

Serrated stress-strain curves were obtained on specimens tested at temperatures ranging from $300^{\circ}$ to $900^{\circ} \mathrm{F}$. These serrations were more noticeable for the high-purity alloy than for the commercial alloy. Discontinuous flow also occurred in specimens of both alloys tested at temperatures above $900^{\circ} \mathrm{F}$. The serrations were interpreted as being associated with strain-aging and other atomic rearrangements, and the discontinuous flow at the higher temperatures as being associated with recrvstallization and grain growth. Strain-aging was also manifested in the strength-temperature relationships of both alloys; it was especially prominent in the curves for tensile and fracture strengths. Variations in composition of the two alloys markedly affected its strength properties (yield, tensile, and fracture) and reduction of area at temperatures below $1,100^{\circ} \mathrm{F}$. Above $1,200^{\circ} \mathrm{F}$, the strength properties for the two alloys were quite similar, but the values obtained for ductility (reduction of area, strain at maximum load, and elongation) were influenced by the composition of the alloys; at $1,200^{\circ} \mathrm{F}$, the ductilities of both alloys were nearly the same.

The rates of work-hardening varied with the test temperature, amount of strain, and composition of the alloys.

The results of hardness tests made at room temperature on specimens of both alloys fractured in tension at different temperatures indicated the predominance of strain-aging and work-hardening at the low range in temperature, a balance of workhardening and recovery in the intermediate range, and the predominance of recrystallization and recovery at the higher temperatures used in the tensile tests. The hardness at room temperature of the fractured specimens was also dependent upon the composition of the alloy and the amount of plastic deformation.

At temperatures below $900^{\circ} \mathrm{F}$, the specimens of both alloys contracted locally before fracturing in a ductile manner with a rim. At temperatures above $900^{\circ} \mathrm{F}$, specimens of both alloys deformed more uniformly before fracturing in a relatively brittle manner without a pronounced rim. The necking and fracture characteristics were also affected by the composition of the alloys.

The final structures and the microcracks produced in the specimens fractured at different temperatures varied with the test temperature, amount of plastic deformation, and composition of the alloys.

\section{References}

[11 G. W. Geil and N. L. Carwile, Tensile properties of copper, nickel, and some copper-nickel alloys at low temperatures, NBS Circular 520, p. 67 (1952).

[21 Nickel and nickel alloys, p. 5 (The International Nickel Co., Inc., Sec. J, 1941).

[31 Nickel and its alloys, NBS Circular 485 (1950).

[4l P. G. McVetty and N. L. Mochel, Tensile properties of stainless iron and other alloys at elevated temperatures, Trans. Am. Soc. Steel Treating 11, 73 (1927).

[5l J. A. Bennett and D. J. McAdam, Jr. Creep rates of cold-drawn nickel-copper alloy (Monel metal), J. Research NBS 28, 417 (1942) RP1462.

[61 D. J. McAdam, Jr., G. W. Geil, and D. H. Woodard, Influence of strain rate and temperature on the mechanical properties of Monel metal and copper, Proc. Am. Soc. Testing Materials 46, 902 (1946).

[7l N. J. Grant and A. G. Bucklin, Creep-rupture and recrystallization of Monel from $700^{\circ}$ to $1,700^{\circ} \mathrm{F}$, Trans. Am. Soc. Metals 45, 151 (1953).

[81 P. Shahinian and J. R. Lane, Influence of grain size on high temperature properties of Monel, Trans. Am. Soc. Metals 45, 177 (1953).

[91 B. B. Betty, H. L. Eiselstein, and F. P. Huston, Creep properties of cold-drawn annealed Monel and Inconel, Trans. Am. Inst. Mining Met. Engrs. 161, 441 (1945)

[101 W. D. Jenkins and T. G. Digges, Effect of temperature on the tensile properties of high-purity nickel, J. Research NBS 48, 313 (1952) RP2317.

Washington, August 4, 1954. 